\title{
WITHIN EACH LAWYER'S CONSCIENCE A TOUCHSTONE: LAW, MORALITY, AND ATTORNEY CIVIL DISOBEDIENCE
}

\section{Robert M. PALUmbos ${ }^{\dagger}$}

Lawyers, like all citizens, inevitably face conflicts between their responsibility to the law and their moral obligations. Attorneys, however, have a unique range of options for resolving such conflicts. They not only have power and privilege in the legal system that other citizens lack, but they also assume a heightened duty to that system and to the law. As the Model Code of Professional Responsibility states, "[t]o lawyers especially, respect for the law should be more than a platitude."

Civil disobedience has become an accepted method for citizens to resist the authority of the state on moral grounds. ${ }^{2}$ By committing civil disobedience ${ }^{3}$ and willingly accepting judicial punishment, one can protest the moral content of a law while still respecting the legal duty it imposes. This Comment addresses whether the current rules of professional ethics leave the option of civil disobedience available to attorneys, and asks under what circumstances attorneys may be justified in exercising that option.

${ }^{\dagger}$ B.A. 1999, The Johns Hopkins University; M.A. 1999, The Johns Hopkins University; J.D. Candidate 2005, University of Pennsylvania. I would like to thank Professor Geoffrey C. Hazard, Jr. for offering his thoughts as I shaped this Comment. I am also grateful to Steve Bero, Melanie McMenamin, and Indraneel Sur for their extraordinarily helpful thoughts on a draft of this Comment.

1 Model Code of Prof'L Responsibility EC 1-5 (1980).

${ }^{2}$ See In re Eastburn, 914 P.2d 1028, 1029 (N.M. 1996) (per curiam) ("Civil disobedience, militant protest, inflammatory rhetoric, and other forms of resistance to established authority have had an important role in the history of democracy."); Lindsey Cowen, The Lawyer's Role in Civil Disobedience, 47 N.C. L. REv. 587, 587 (1969) ("[I]t appears that most persons who have written on the subject believe that under certain circumstances conduct that is illegal, and therefore punishable by the state, may nevertheless be morally justified.”); Monroe H. Freedman, Legal Ethics from a Jewish Perspective, 27 TEX. TECH L. REV. 1131, 1138 (1996) (noting that the author, a law professor, supported civil disobedience against the Vietnam War and himself committed civil disobedience); William H. Pryor, Jr., Christian Duty and the Rule of Law, 34 CUMB. L. REV. 1, 8 (2003) (implying that the author, the sitting Attorney General of Alabama, believed civil disobedience was justified under certain circumstances to protest unjust laws).

"I will use "civil disobedience," "conscientious noncompliance," and other related terms interchangeably to refer to "the violation of law by nonviolent means where opposition to the law is based on a deeply held conviction that the law itself is in conflict with some higher principle." Robert B. McKay, Civil Disobedience: A New Credo?, 2 GA. L. REV. 16, 19 (1967). 
Attorney civil disobedience is hardly novel. The man who famously demonstrated the power of civil disobedience to the world, Mohandas Gandhi, was trained in the English common law system and practiced law for more than twenty years. ${ }^{4}$ Far from being an obstacle to moral reform, Gandhi's legal training was instrumental in the development of nonviolent resistance to British imperial control of India. Gandhi maintained a very lawyerly respect for the law and the legal system even as he defied it. ${ }^{5}$ This Comment explores the extent to which the American bar has accepted Gandhi's example of reform for its own lawyers.

After reviewing the moral and philosophical justifications for civil disobedience in Part I, I will examine the codes of professional ethics ${ }^{6}$ and related case law in Part II to determine the position of the organized bar on attorney civil disobedience. This discussion makes clear that, despite the bar's insistence in its official rules that its members obey and respect the law, there is a measure of unofficial tolerance for conscientious noncompliance by lawyers. Unfortunately, it remains uncertain from the application of the ethics rules how far this tolerance goes.

Part III addresses normative arguments for and against permitting lawyers to engage in civil disobedience in light of the legal profession's relationship to law and society. I argue that the main criticisms of attorney civil disobedience overlook key elements of the bar's relationship to the law, to the public, and to the legal system. While lawyers should be cognizant of a heightened responsibility to obey the law, the theoretical and practical arguments in favor of allowing them to commit civil disobedience, under some circumstances, are stronger than those in opposition.

\footnotetext{
${ }^{4}$ John Leubsdorf, Gandhi’s Legal Ethics, 51 RUTGERs L. REV. 923, 923 (1999).

${ }_{5}^{5}$ See id. at 938-39 (describing the respect with which Gandhi submitted himself to the law's judgment as an important part of his philosophy).

${ }^{6}$ Unless otherwise specified, I will use the terms "codes of ethics" or "ethics rules" to refer collectively to the Model Code of Professional Responsibility (Model Code) and the Model Rules of Professional Conduct (Model Rules), promulgated by the American Bar Association and now binding in most states. See ABA Compendium OF Prof'L RESPONSIBILITy Rules AND StANDARdS 637 (2004) [hereinafter ABA COMPENDIUM] (listing the forty-five jurisdictions that have adopted the Model Rules). Though the Model Rules superceded the Model Code in 1983, I will consider both the Model Code and the Model Rules in this Comment. The Model Code remains relevant because "many provisions of the Model Rules are based on provisions of the Code.” NATHAN M. CRystal, AN INTRODUCTION to PROfESSIONAL RESPONSIBILITY 7 (1998). In addition, prior court decisions based on the Model Code still hold true under the Model Rules. Id. Thus, discussing the approach of the Model Code towards attorney civil disobedience provides a broader and more accurate view of the bar's attitude on this issue.
} 
Finally, in Part IV, I will elaborate on the circumstances in which attorney disobedience is justified. I propose to amend the rules of legal ethics to acknowledge explicitly that attorneys should subject the law to some personal moral scrutiny. By recognizing that moral obligations may overcome legal duties, the canons of legal ethics will strengthen an important safeguard against injustice. However, since it is appropriate that attorneys exercise a greater degree of caution than other citizens before committing civil disobedience, the rules should establish clear consequences for justified noncompliance. Currently, attorneys face a high-stakes gamble as to how the bar's disciplinary bodies will respond to their disobedience. Leaving their careers to the whims of the profession's disciplinary discretion makes the cost of attorney civil disobedience too high. Yet, imposing some professional consequences on attorneys is appropriate because it will make them evaluate more rigorously the principle for which they are willing to break the law and consider the social costs of their disobedience.

\section{THE PURPOSES OF AND JUSTIFICATIONS FOR CIVIL DISOBEDIENCE}

The concept of justified civil disobedience has deep roots in our jurisprudence and has survived challenges to its philosophical foundations. ${ }^{7}$ Traditional natural law theory, which has influenced Western legal tradition for centuries, ${ }^{8}$ posits a necessary connection between law and morality. ${ }^{9}$ Best illustrated by St. Augustine's proposition that "an unjust law is no law at all," natural law theory claims that a law

${ }^{7}$ See United States v. Dorrell, 758 F.2d 427, 435 (9th Cir. 1985) (Ferguson, J., concurring) ("Civil disobedience has a long heritage in this country, beginning as far back as the Boston Tea Party.").

${ }^{8}$ See Jeffrie G. Murphy \& Jules L. Coleman, Philosophy of Law: AN INTRODUCTION TO JURISPRUDENCE 12-14 (rev. ed. 1990) (describing the development of natural law theory by Plato, Aristotle, Cicero, and St. Thomas Aquinas, as well as its reformulation by the thinkers of the Enlightenment and the French and American Revolutions).

${ }^{9}$ See id. at 11 ("Natural law theories maintain that there is an essential (conceptual, logical, necessary) connection between law and morality. ... [A]ccording to natural law theory, it is part of the very meaning of 'law' that it passes a moral test."); see also LARRY AleXANDER \& EMily SHERWIN, THE Rule OF Rules: MORAlity, Rules, AND THE DILEMMAS OF LAW 184 (2001) (describing the natural law proposition that "law must be essentially connected with morality").

${ }^{10}$ Augustine, ON Free ChOICE OF THE Will 8 (Thomas Williams trans., Hackett Publ'g Co. 1993) (ca. 395). This quote has been called a "slogan" of natural law, see MURPHY \& COLEMAN, supra note 8, at 11, and was used by Martin Luther King, Jr., to justify his own civil disobedience, see MARTIN LUTHER KING, JR., Letter from Birmingham Jail, in WHY WE CAN'T WAIT 76, 82 (1964), available at http://www.stanford.edu/ 
lacking moral legitimacy is not legally valid. ${ }^{11}$ Legal positivism, which grew out of the Enlightenment in reaction to natural law theory, ${ }^{12}$ severed the essential link between law and morality. ${ }^{13}$ Whereas natural law theory understands legal validity as a normative category, positivism treats it as a purely descriptive one. Positivists look to a law's pedigree-not its moral content-to determine its legal legitimacy. ${ }^{14}$ Valid laws are those issued by the sovereign in accordance with the "rule of recognition" of the legal system. ${ }^{15}$ They impose an obligation on citizens to obey, and they become a standard within the society for criticizing and justifying behavior. ${ }^{16}$

It was against the background of the debate between natural law and positivism that Henry David Thoreau, the "father" of modern-day civil disobedience, ${ }^{17}$ developed his understanding of one's right to break the law. Thoreau accepted the positivist perspective that morally repugnant laws were still legally binding, but claimed that his

group/King/popular_requests/frequentdocs/birmingham.pdf (last visited Dec. 31, 2004).

${ }^{11}$ AlEXANDER \& SHERWIN, supra note 9, at 187 (characterizing the natural law perspective that laws "can be normative in the way they claim only if they are consistent with moral norms").

${ }^{12}$ MurPhy \& Coleman, supra note 8, at 19. Enlightenment figures such as Thomas Hobbes and Immanuel Kant shifted jurisprudential inquiry away from natural law theory and laid the groundwork for John Austin's system of positivism. See THOMAS Hobbes, Leviathan 185 (Richard Tuck ed., Cambridge Univ. Press 1991) (1651) (" $[\mathrm{E}]$ very subject in a Common-wealth ... hath covenanted to obey the Civill [sic] Law”); IMMANUEL KANT, THE MeTAPHYSICS OF MoRALS 55 (Mary Gregor trans., Cambridge Univ. Press 1991) (1797) (arguing that one can inquire into what is legal without inquiring into what is moral).

13 See AleXANDER \& SHERWIn, supra note 9, at 188 (describing the positivist position as one that recognizes the sovereign's rules as law even if those rules are "terribly immoral"); H.L.A. HART, THE CONCEPT OF LAW 185-86 (2d ed. 1994) (defining positivism as "the simple contention that it is in no sense a necessary truth that laws reproduce or satisfy certain demands of morality").

${ }^{14}$ See MURPHY \& COLEMAN, supra note 8, at 22 (noting Austin's argument that under positivism "the legal is distinguished from the nonlegal in terms of pedigree," not morality).

${ }^{15}$ See HART, supra note 13 , at 100 ("Wherever such a rule of recognition is accepted, both private persons and officials are provided with authoritative criteria for identifying primary rules of obligation."); $c f$. 1 JOHN AUSTIN, LECTURES ON JURISPRUDENCE 6-11 (Robert Campbell ed., Jersey City, Frederick D. Linn \& Co. 1875) (arguing that laws are commands by the sovereign backed by threat of force, not moral authority).

${ }^{16}$ See HART, supra note 13, at 55-56 (noting that a law, unlike a custom or habit, becomes a measure for criticizing behavior and a justification for demanding certain actions).

${ }^{17}$ Cowen, supra note 2, at 588 n.6; Kenneth Jost, Opinion, Oliver North and the Son of Sam, Christian SCI. MONiTOR, Nov. 4, 1991, at 18. 
moral obligations could nevertheless outweigh his duty to obey the law. ${ }^{18}$ Arguing that even a just government authorized by "the sanction and consent of the governed" had "no pure right over [his] person and property," 19 Thoreau chose to withhold his taxes and accept imprisonment rather than fund the government's support for slavery and its engagement in the Mexican War. ${ }^{20}$ Thus was born the modern concept of civil disobedience, under which "[p] ersons are thought to be justified in violating the law if, but only if, they are prepared to be punished for their disobedience."21

Positivism remains, by and large, the dominant American approach toward legal ethics today. ${ }^{22}$ Nevertheless, the history of the twentieth century strongly impressed upon Western culture the tragic potential of obeying laws merely because they are legally valid. We fear what William Simon described as the "nightmarish slippery slope of Positivism" that "leads to compliance with jurisdictionally adequate but morally evil laws like the Nazi enactments requiring reporting Jews and dissidents or the antebellum Fugitive Slave Laws." ${ }^{23}$ We have seen

${ }^{18}$ See Henry David Thoreau, Walden and Civil Disobedience 231 (Owen Thomas ed., W.W. Norton \& Co. 1966) (1849) (declaring that it is better to break the law than to be the "agent of injustice" through one's obedience).

${ }^{19} I d$. at 243.

${ }^{20}$ See id. at 228 (discussing the need to "do justice to the slave and to Mexico"); see also United States v. Dorrell, 758 F.2d 427, 435 (9th Cir. 1985) (Ferguson, J., concurring) ("Some, like Thoreau, chose to refrain from society's fundamental obligation to pay taxes for the common benefit in order to express their repugnance to a government that fostered slavery.").

${ }^{21}$ Heidi M. HuRd, MORAL COMBat 274-75 (1999); see also KING, supra note 10, at 83-84 ("I submit that an individual who breaks a law that conscience tells him is unjust, and who willingly accepts the penalty of imprisonment in order to arouse the conscience of the community over its injustice, is in reality expressing the highest respect for law."); Pryor, supra note 2, at 8 (contrasting civil disobedience, in which the individual accepts punishment, with lawbreaking in which an individual seeks to evade punishment).

${ }^{22}$ Cf. William H. Simon, The Practice of Justice: A Theory of Lawyers' ETHICS 37 (1998) ("Legal ethics is the only area in which [practicing lawyers] continue to cling to [the positivist approach].") Few would seriously argue the traditional natural law position that an unjust law lacks legal validity. See MurPhy \& Coleman, supra note 8 , at 7, 11-12 (criticizing natural law theory for insisting that "no rule can count as law unless what it requires is at least morally permissible" and thus failing to realize the obvious fact that "law and morality are in some sense different even if closely related"); David Luban, Conscientious Lawyers for Conscientious Lawbreakers, 52 U. PITT. L. REV. 793, 801 (1991) (noting that "natural law theories are quite out of favor with contemporary lawyers").

${ }^{23}$ William H. Simon, Should Lawyers Obey the Law?, 38 WM. \& MARY L. REV. 217, 224 (1996); see also Maura Strassberg, Taking Ethics Seriously: Beyond Positivist Jurisprudence in Legal Ethics, 80 IOWA L. REV. 901, 916-17 (1995) (recounting the argument that "the 
the reality of legal regimes that were so unjust that noncompliance with them became, to some, a moral obligation superceding the legal duty to obey the law. ${ }^{24}$ Modern advocates of positivism have recognized the need for some moral inquiry into a citizen's duty to the law, noting that "the certification of something as legally valid is not conclusive of the question of obedience." ${ }^{25}$ Consequently, though mainstream American society rejects classical natural law theory, it also resists a categorical duty to obey valid $\operatorname{laws}^{26}$ and recognizes civil disobedience as a valid form of protest and a valid democratic check on unjust laws. ${ }^{27}$

Though the right of citizens to engage in civil disobedience is widely accepted, it remains highly contested whether attorneys have (or should have) the same right. ${ }^{28}$ This is clearly a significant question for our society generally and for lawyers in particular. Attorneys enjoy unique privilege and power within the judicial system; their rights, status, and actions inherently affect our legal environment in ways that those of other citizens do not. Our willingness as a society-and the bar's willingness as a profession-to tolerate attorney noncompliance

actions of the German legal community under the Nazis resulted from the modern positivist attempt to maintain the distinction between legal and moral validity").

${ }^{24}$ See KING, supra note 10, at 84 (justifying the violation of unjust laws in Nazi Germany and communist countries); Stephen Ellmann, To Live Outside the Law You Must Be Honest: Bram Fischer and the Meaning of Integrity, 26 N.C. J. INT'L L. \& COM. REG. 767, 768-70 (2001) (describing lawbreaking by judicial actors within the South African apartheid system).

${ }^{25}$ See HART, supra note 13, at 210 ("[Men] should preserve the sense that the certification of something as legally valid is not conclusive of the question of obedience, and that ... its demands must in the end be submitted to a moral scrutiny.").

${ }^{26}$ Id.; Simon, supra note 23, at 228 ("Mainstream American legal culture incorporates both Positivist and Substantive perspectives, giving emphasis to one or the other in some areas, while trying awkwardly to synthesize them in others."); Strassberg, supra note 23, at 905 (stating Ronald Dworkin's position that "recognizing the inherent legitimacy of much civil disobedience is fundamental to overcoming the separation between law and morality").

27 See supra note 2.

28 Compare David Luban, Legal Ideals and Moral Obligations: A Comment on Simon, 38 WM. \& MARY L. REV. 255, 259 (1996) (“[B] ecause lawyers are often better positioned than nonlawyers to realize the unfairness or unreasonableness of a law, lawyers often should be among the first to violate or nullify it, or to counsel others that it is acceptable to violate or nullify it."), and Simon, supra note 23, at 218 (arguing that the dominant view on legal ethics is skewed far too heavily in the positivist direction, restricting a lawyer's ability to facilitate a moral outcome), with Timothy P. Terrell, Toward DutyBased Lawyering?: Rethinking the Dangers of Lawyer Civil Disobedience in the Current Era of Regulation, 54 ALA. L. REV. 831, 834-35 (2003) (claiming that lawyer civil disobedience should be discouraged because it necessarily undermines the legal system's claim to legitimacy). 
illuminate the American attorney's relationship to the law in several ways.

First, the acceptability of civil disobedience by lawyers necessarily reflects a judgment about the interests that attorneys represent. Our position on this issue reveals whether we view lawyers purely as agents mediating the respective interests of their clients and the state, or whether we also consider them accountable to society for broader moral interests. Second, since one justification for civil disobedience is that there is a personal right to violate the law out of moral obligation, ${ }^{29}$ forbidding attorney noncompliance strips lawyers of a prerogative that has come to be understood as a basic element of citizenship. It is prudent to recognize explicitly whether this sacrifice is one of the collateral effects of the decision to be an attorney.

Third, since lawyers are among the primary actors implementing the state's edicts, their capacity to disobey unjust or evil laws is particularly relevant to our concern about the slippery slope of positivism. ${ }^{30}$ Given the powerful role of attorneys in the legal system-both practical and symbolic-their acts of noncompliance will almost certainly have a greater impact (for good and bad) than those of other citizens. Finally, the issue of lawyer civil disobedience potentially restricts the type of laws that can be justifiably disobeyed. Since there are some legal obligations imposed only on attorneys by virtue of their profession, ${ }^{31}$ these rules may only be disobeyed by attorneys. ${ }^{32}$ A determination that lawyer disobedience is prohibited would mean that these laws are not considered susceptible to noncompliance, a proposition that contradicts our society's general acceptance of the concept of civil disobedience.

${ }^{29}$ Cf. United States v. Sisson, 297 F. Supp. 902, 910 (D. Mass. 1969) ("When the state through its laws seeks to override reasonable moral commitments it makes a dangerously uncharacteristic choice."); THOREAU, supra note 18, at 243 (“[T]o be strictly just, [government] must have the sanction and consent of the governed. It can have no pure right over my person and property but what I concede to it.").

${ }^{30}$ See Strassberg, supra note 23, at 916 (noting that "judges and lawyers obeyed and enforced [the] 'valid' laws" of Nazi Germany).

${ }^{31}$ See, e.g., PA. RULES OF PROF'L CONDUCT 1 (2001) (establishing legally binding rules of professional responsibility for attorneys admitted to the Pennsylvania bar).

${ }^{32}$ See, e.g., 1 Geoffrey C. HAZARD, JR. \& W. William Hodes, The LaW of LAWYERING \$9.20 (3d ed. Supp. 2003) (noting that under the original Model Rule 1.6 (b) (1) (amended in 2002, see infra note 57), a lawyer would have had to violate the requirement of client confidentiality in order to save a life, and suggesting that an attorney in this situation would be justified in engaging in civil disobedience). 


\section{The Treatment of AtTorney Civil Disobedience Under THE CODES OF PROFESSIONAL ETHICS}

Lawyer civil disobedience differs from that of other citizens because attorneys are subject to binding professional rules of ethics to which they alone must answer. ${ }^{33}$ This fact allows for attorney civil disobedience in two possible forms: (1) violations of substantive law, and (2) violations of binding professional ethics requirements. ${ }^{34}$ With respect to the former, attorneys, like all other citizens, are subject to criminal liability. Unlike other citizens, however, attorneys also face potential punishment under their codes of ethics for such lawbreaking. ${ }^{35}$ The latter form of civil disobedience is available only to lawyers and punishable under professional disciplinary rules, not the criminal law. ${ }^{36}$ This discussion will not distinguish between the two forms of lawyer disobedience because the operative question is the same for both types: what are the consequences to an attorney under the codes of professional ethics for conscientiously violating legally binding rules? $^{37}$

${ }^{33}$ See Strassberg, supra note 23, at 904 ("In all fifty states, lawyers are governed and will continued [sic] to be governed by positive rules.").

${ }^{34}$ See Mary C. Daly, To Betray Once? To Betray Twice?: Reflections on Confidentiality, A Guilty Client, an Innocent Condemned Man, and an Ethics-Seeking Defense Counsel, 29 LoY. L.A. L. REV. 1611, 1628-29 (1996) (describing violation of ethics rules for moral reasons as civil disobedience).

${ }^{35}$ See infra text accompanying notes 39-46 (describing the characterization of lawbreaking by attorneys as misconduct under professional norms).

${ }^{36}$ See Model Code of Prof'L ResPonsibility EC 7-1 (stating that the "bounds of the law" include enforceable professional regulations in addition to substantive law); see also supra note 32 (describing an attorney's breach of client confidentiality as potential civil disobedience).

${ }_{37}$ There is a significant body of literature that discusses the professional ethics problems an attorney faces while representing clients contemplating civil disobedience, including: Geoffrey C. Hazard, Jr., How Far May a Lawyer Go in Assisting a Client in Legally Wrongful Conduct?, 35 U. MiAMI L. Rev. 669 (1981); Luban, supra note 22, at 793-98; Martha Minow, Breaking the Law: Lawyers and Clients in Struggles for Social Change, 52 U. PITT. L. Rev. 723 (1991); Joel S. Newman, Legal Advice Toward Illegal Ends, 28 U. RICH. L. REv. 287 (1994); Stephen L. Pepper, Counseling at the Limits of the Law: An Exercise in the Jurisprudence and Ethics of Lawyering, 104 YALE L.J. 1545 (1995). Such representation could theoretically constitute attorney disobedience to the ethical codes, which prohibit lawyers from counseling or assisting a client "in conduct that the lawyer knows is criminal.” MOdel Rules of Prof'L CONDuct R. 1.2(d) (2003); see also MOdEL Code OF PROF'L RESPONSIBILITY DR 7-102(A) (“[A] lawyer shall not . . . [c] ounsel or assist his client in conduct that the lawyer knows to be illegal...."). These representational issues, however, are largely beyond the scope of this Comment. Though they might be characterized as questions about attorney disobedience to the rule of law, these issues involve very thorny problems of client autonomy, role morality, and the attorney's gatekeeper function in the legal system. See, e.g., DAVID LUBAN, LAWYERS AND JUSTICE: 
The codes of ethics present a striking obstacle to answering this question. The ethics rules impose seemingly conflicting duties on lawyers with respect to civil disobedience. ${ }^{38}$ On the one hand, the codes state in no uncertain terms that lawyers have a "duty to uphold legal process" ${ }^{39}$ and to show respect for the law by obeying it. ${ }^{40}$ Both the Model Rules of Professional Conduct (Model Rules) and the Model Code of Professional Responsibility (Model Code) explicitly define professional misconduct to include illegal actions. The Model Code states that a "lawyer shall not ... [e]ngage in illegal conduct involving moral turpitude" or "any other conduct that adversely reflects on his fitness to practice law." violations of law by a lawyer," ${ }^{42}$ and holds attorneys responsible for the law at all times, regardless of whether they are acting in their professional or personal capacities. ${ }^{43}$ The Model Rules establish that it is

AN ETHICAL STUDY 148-66 (1988) (discussing the dominant principle of nonaccountability of attorneys for the decisions of their clients). Such issues are related to, but distinct from, the question of whether attorneys may violate the law for moral reasons outside of their representational roles; these deserve separate attention.

Moreover, while important unresolved questions remain about representing clients considering conscientious lawbreaking, there appears already to be greater agreement in the legal community about the propriety of such representation than there is about actual attorney disobedience. See MODEL RUles OF PROF'L CONDUCT R. 1.2(d) cmt. 6 (" $[\mathrm{T}]$ he fact that a client uses advice in a course of action that is criminal or fraudulent does not of itself make a lawyer a party to the course of action."); Newman, supra, at 29092 (arguing that the professional codes of ethics clearly allow an attorney to give neutral legal advice to a client that will likely be used to commit a crime); Press Release, National Lawyers Guild, National Lawyers Guild Supports Acts of Civil Disobedience in Protesting Preemptive Strike Against Iraq (Oct. 3, 2002) (announcing intent to provide legal support and materials to individuals and groups considering civil disobedience), available at http://www.nlg.org/news/statements/iraq_cd.htm (last visited Dec. 31, 2004).

${ }^{38}$ See Judith A. McMorrow, Civil Disobedience and the Lawyer's Obligation to the Law, 48 WASH. \& LEE L. REV. 139, 139-41 (1991) (discussing how a lawyer's "special obligations both to uphold the law and to strive to make the law just" make it unclear whether attorneys may commit civil disobedience).

${ }^{39}$ Model Rules of Prof'L Conduct Preamble para. 5.

40 See Model Code of Prof'L Responsibility EC 1-5 (“Obedience to law exemplifies respect for the law. To lawyers especially, respect for the law should be more than a platitude."); ABA Young Lawyers Div., Lawyer's Pledge of Professionalism, in ABA COMPENDIUM, supra note 6, at 437 ("I will encourage respect for the law and our legal system through my words and actions.”).

${ }^{41}$ Model Code of Prof'L Responsibility DR 1-102(A); see also id. EC 1-5 (declaring that attorneys should "refrain from all illegal and morally reprehensible conduct").

${ }^{42}$ See id. EC 1-5 ("[E]ven minor violations of law by a lawyer may tend to lessen public confidence in the legal profession.").

${ }^{43}$ See id. (stating that a lawyer's duty to demonstrate respect for the law and the legal profession is due to "his position in society" as an attorney); McMorrow, supra 
"professional misconduct for a lawyer to ... commit a criminal act that reflects adversely on the lawyer's honesty, trustworthiness or fitness as a lawyer." Thus, compared to the Model Code, the Model Rules narrow the scope and degree of illegal conduct for which attorneys are responsible. ${ }^{45}$ Nevertheless, a pattern of minor violations remains sufficient to discipline an attorney under the Model Rules, including the use of temporary or permanent disbarment. ${ }^{46}$

Taken by itself, such language would prohibit attorney civil disobedience fairly clearly. The ethics rules, however, also impose on lawyers a duty to improve the law by seeking to make it more just. The Model Code advises attorneys to "[a]ssist in [i]mproving the [1] egal $[\mathrm{s}] \mathrm{ystem} "$ and to strive to make the law more "just, understandable, and responsive to the needs of society." emphasize that lawyers should improve the law and the legal system. ${ }^{49}$

Thus, the professional rules of ethics place on lawyers two sets of responsibilities that intersect and conflict on the question of conscientious lawbreaking. Civil disobedience is one potential mechanism by

note 38, at 152 (noting that, under the Model Code, the ABA rejected "any distinction between professional and personal conduct, stating that a lawyer must comply with applicable rules at all times"); see also In re Preston, 616 P.2d 1, 5 (Alaska 1980) (rejecting attorney's contention that he should not be disciplined for illegal conduct because it "was unrelated to his professional skill and ability to practice law").

${ }^{44}$ MODEL RULeS OF PROF'L CONDUCT R. 8.4.

45 See id. R. $8.4 \mathrm{cmt}$. 2 ("Although a lawyer is personally answerable to the entire criminal law, a lawyer should be professionally answerable only for offenses that indicate lack of those characteristics relevant to law practice."); William H. Simon, Moral Pluck: Legal Ethics in Popular Culture, 101 ColuM. L. REV. 421, 424 n.13 (2001) (describing the Model Rules as taking "a more moderate line" on violations of the law by attorneys than the Model Code).

${ }^{46}$ See Model Rules of Prof'L CONDUCt R. $8.4 \mathrm{cmt}$. 2 ("A pattern of repeated offenses, even ones of minor significance when considered separately, can indicate indifference to legal obligation."); Strassberg, supra note 23, at 902 n.14 (criticizing David Luban's proposal for giving attorneys who commit justified civil disobedience "no comfort that their careers will or should survive"); Terrell, supra note 28, at 835-36 (noting that attorney civil disobedience risks the punishment of disbarment).

${ }^{47}$ Model Code of Prof'L ReSPONSIBILITY Canon 8.

${ }^{48}$ Id. EC 8-2; see also id. EC 8-9 ("The advancement of our legal system is of vital importance in maintaining the rule of law and in facilitating orderly changes; therefore, lawyers should encourage, and should aid in making, needed changes and improvements.").

${ }^{49}$ See MOdel Rules OF Prof'L CONDUCT Preamble para. 6 (“[A] lawyer should seek improvement of the law, access to the legal system, the administration of justice and the quality of service rendered by the legal profession."); $i d$. Preamble para. 7 ("A lawyer should strive... to improve the law and the legal profession ...."); id. R. 6.1(b) (3) (emphasizing that lawyers should participate "in activities for improving the law, the legal system or the legal profession”). 
which lawyers might seek to make the law-or the rules governing the legal profession-more just. ${ }^{50}$ Yet, the rules appear to forbid such well-intended lawbreaking.

One possible solution to this conflict, identified in the Model Code, is simply to limit an attorney's efforts to improve the law to "lawful means., ${ }^{51}$ This resolution is deficient in three respects. First, the Model Rules lack a similar restriction. ${ }^{52}$ Second, the Model Code's limitation on attorney disobedience is in tension with its claim that "[e]ach lawyer must find within his own conscience the touchstone against which to test the extent to which his actions" are ethical. ${ }^{53}$ Likewise, the Model Rules note that a lawyer's professional duties must be informed by "personal conscience," not merely the obligations imposed by the black letter words of the codes of ethics. ${ }^{54}$ The spirit of such advice surely opens the door, however slightly, to attorney civil disobedience. Finally, attorneys may face circumstances in which lawful efforts to improve the law or prevent injustice are either ineffective or impossible. ${ }^{55}$

Consider, for example, a case in which a client tells her lawyer that she committed the crime for which another person is about to be executed. ${ }^{56}$ Until 2002, if a client refused to waive confidentiality, the law-

${ }^{50}$ See HAZARD \& HODES, supra note $32, \S 9.20$ (suggesting that if a lawyer violated a professional ethics rule on moral grounds, "[t]he publicity arising from such a case might well lead to salutary changes in the law-a hallmark of conscientious civil disobedience"); Leslie Griffin, The Relevance of Religion to a Lawyer's Work: Legal Ethics, 66 FORDHAM L. REV. 1253, 1261 (1998) (arguing that civil disobedience is one option for criticizing an unjust law and that "the legal profession needs criticism to improve its own standards").

${ }^{51}$ Cf. MODEL CODE OF PROF'L Responsibility EC 8-2 (stating that a lawyer "should endeavor by lawful means to obtain appropriate changes in the law").

${ }^{52}$ See Model Rules of Prof'L Conduct R. 6.1(b) (3) (stating that a lawyer should "provide any additional services through ... participation in activities for improving the law, the legal system or the legal profession" (emphasis added)); $i d$. R. $6.1 \mathrm{cmt} .8$ (providing a nonexhaustive list of examples of how a lawyer may work to improve the law); cf. supra note 45 and accompanying text (noting that the Model Rules adopt a more moderate approach to illegal lawyer conduct).

53 MODEL CODE OF PROF'L RESPONSIBILITY Preamble.

${ }^{54}$ See Model Rules of Prof'L Conduct Preamble para. 7 ("Many of a lawyer's professional responsibilities are prescribed in the Rules of Professional Conduct, as well as substantive and procedural law. However, a lawyer is also guided by personal conscience and the approbation of professional peers.").

${ }^{55}$ See Minow, supra note 37, at 727-39 (describing the limits on lawful reform, the potential negative consequences in pursuing it, and the advantages that civil disobedience offers in certain situations).

${ }^{56}$ See Monroe H. Freedman, The Life-Saving Exception to Confidentiality: Restating Law Without the Was, the Will Be, or the Ought to Be, 29 LOY. L.A. L. REV. 1631, 1632, 
yer would have been prohibited by the Model Rules from taking steps to prevent the execution. ${ }^{57}$ In essence, the lawyer had no "lawful" options at her disposal to ensure a just result. ${ }^{58}$ In such instances, disobeying the law may be the most ethical course of action because it is the only way to prevent the legal system from committing a grave injustice. The "lawful reform" limitation fails to take such situations into account.

The case law offers little help in resolving this conflict or in clarifying what the consequences of conscientious noncompliance are under the codes of ethics. There are few instances on record in which practicing attorneys have committed civil disobedience and been subject to disciplinary proceedings. ${ }^{59}$ Professor Monroe Freedman provides a personal account of what is perhaps the prototypical example of attorney civil disobedience. Freedman writes that he "openly violated the rules against advertising and solicitation, intentionally courting disciplinary action, because [he] believed that those rules deprived poor and unsophisticated people of essential information about their rights. ${ }^{\circledR 60}$ The District of Columbia Bar Association brought disciplinary charges against Professor Freedman, but eventually agreed with his position and issued "the first opinion anywhere approving advertising and solicitation of clients." ${ }^{, 61}$ He notes that "[w] hen asked by

1636-37 (1996) (arguing that client confidentiality should be violated in the face of the loss of an innocent life). Perhaps the best known example of a life-or-death professional ethics problem occurred in Spaulding v. Zimmerman, 116 N.W.2d 704 (Minn. 1962). Attorneys for a defendant in a personal injury suit involving a car accident discovered that the plaintiff had a potentially fatal aneurysm which may or may not have been caused by the accident. Id. at 707. It was clear that the plaintiff was unaware of the condition. $I d$. at 708 . The defense attorneys completed settlement negotiations and never informed the plaintiff of the aneurysm, out of respect for their client's interests in the case. $I d$.

${ }^{57}$ In 2002, Rule 1.6 of the Model Rules was amended to permit breaches of client confidentiality in order "to prevent reasonably certain death." MODEL RULES OF PROF'L CONDUCT R. 1.6(b) (1). The change in this Rule illustrates that the law governing attorneys, like other positive law, can and should evolve to accommodate overriding moral principles.

${ }^{58}$ I assume that, in this situation, an attorney's "noisy withdrawal" would not have been helpful to the innocent defendant. See id. R. $1.16 \mathrm{cmt}$. 7 (noting that an attorney, in such situations, might be permitted to withdraw representation).

${ }^{59}$ See Daly, supra note 34, at 1628 (noting that the author had "located no instances of civil disobedience directed to the judicial branch in its capacity as the regulator of the legal profession"); Griffin, supra note 50, at $1260 \mathrm{n} .17$ (admitting that the author did "not know how often civil disobedience ha[d] been invoked in disciplinary settings").

${ }^{60}$ Freedman, supra note 2, at 1137.

${ }^{61} I d$. Professor Freedman also writes that he engaged in civil disobedience several 
reporters and others how I, as a lawyer, could commit civil disobedience, I answered, 'I was a free person, with moral responsibility, before I was a lawyer." "62

Some lawyers have raised a civil disobedience defense to lawbreaking that courts found lacking in moral justification. ${ }^{63}$ Though such defenses were unsuccessful, the willingness of courts and disciplinary boards to consider them suggests that there may indeed be a role for conscientious disobedience in professional ethics cases. One state bar committee stated that "a single act of civil disobedience did not call into question an attorney's fitness to practice law," but that "frequent and/or continual misdemeanor convictions of this nature may result in more serious professional consequences." ${ }^{, 64}$

The treatment of applicants for admission to the bar provides a fair-though imperfect-comparison of how the rules of ethics are interpreted with regard to civil disobedience. ${ }^{65}$ The certification process is analogous to disciplinary proceedings in that state bars require applicants, like their members, to be of good moral character. $^{66}$ Criminal conduct in both contexts reflects on an attorney's moral fitness because it shows a lack of respect for the law. ${ }^{67}$ The re-

times to protest the Vietnam War, but does not mention whether disciplinary action resulted from these acts. $I d$. at 1138 .

${ }^{62} I d$. at 1138.

63 See In re Preston, 616 P.2d 1, 4 (Alaska 1980) (noting that the Disciplinary Board of the Alaska Bar Association concluded that an attorney's distribution of drugs was not an act of civil disobedience intended to change the law); In re Disciplinary Action Against Stanbury, 561 N.W.2d 507, 511 (Minn. 1997) (rejecting attorney's claim that his failure to pay court fees was an act of civil disobedience and holding that "it is not the system that is in need of reexamination and reform," but rather the defendant).

${ }^{64}$ McMorrow, supra note 38, at 154 (citing Virginia Legal Ethics Opinion No. 1185, VA. LAW. REGISTER, Oct. 1989, at 14).

${ }^{65}$ The comparison between the certification process and disciplinary proceedings is limited by the fact that certification is based on more stringent requirements than disciplinary review. See Deborah L. Rhode, Moral Character as a Professional Credential, 94 YALE L.J. 491, 547 (1985) (describing the "double standard" between the admission and disciplinary processes that results because "both substantive and procedural requirements are more solicitous of practitioners than applicants"). Consequently, illegal conduct is more likely to be flagged during an admissions inquiry as a sign of moral deficiency than in the context of disciplinary action against a practicing attorney.

${ }^{66}$ See Konigsberg v. State Bar of Cal., 353 U.S. 252, 273 (1957) (recognizing the importance of allowing state bars to select their own members, but adding that these members should be of good character); MODEL CODE OF PROF'L RESPONSIBILITY EC 12 (stating that applicants to the bar who are deficient in moral standards are not qualified); Rhode, supra note 65 , at 546 ("[T] he justification for regulating the personal behavior of licensed attorneys is in many respects analogous to that underlying the certification process.").

${ }^{67}$ See Rhode, supra note 65, at 537 (noting that applicants are often rejected from 
sponse of bar committees to applicants with civil disobedience in their background varies widely. Some states see politically or morally motivated lawbreaking as deeply problematic for bar admission, while others see it as almost admirable. ${ }^{68}$ The California Supreme Court, for example, held that an applicant's multiple arrests in the context of the civil rights movement did not disqualify him from the practice of law, noting that such noncompliance might be considered a product of "the highest moral courage." 69 By contrast, Illinois denied admission to a conscientious objector to World War II on the grounds that his pacifist views prevented him from complying with a state constitutional requirement that applicants serve in the state's militia during time of war. ${ }^{70}$ Thus, while the treatment of bar applicants suggests that there is some tolerance of civil disobedience among the bars, the states differ too widely in this respect to draw any clear lessons.

Part of the difficulty in determining the consequences of civil disobedience under the rules of ethics is simply that the codes themselves, like nearly every other form of positive law, are subject to many reasonable interpretations. ${ }^{71}$ To prohibit illegal conduct that involves "moral turpitude",72 or "reflects adversely on the lawyer's honesty, trustworthiness or fitness as a lawyer" invites the disciplinary boards to inject subjective values, including their own sense of morality, into

bar admission due to illegal activities, "regardless of the likelihood of their repetition in a lawyer-client relationship," because they "would demean the profession's reputation"). The primary difference between disciplinary procedures and bar admission inquiries is that in the former, the bar bears the burden of showing the attorney's moral deficiency, while in the latter, applicants bear the burden of showing their own moral fitness. See Hallinan v. Comm. of Bar Examiners, 421 P.2d 76, 80 (Cal. 1966) (stating that applicants to the bar bear the burden of showing moral fitness, while the bar bears the burden of proving attorneys are unfit during disciplinary hearings); Rhode, supra note 65, at 547 (same).

${ }^{68}$ See Rhode, supra note 65 , at 542-43 (describing the variety of reactions to an applicant's arrest in connection with political activity among the bars of Arkansas, California, Idaho, Missouri, New York, Nevada, and Virginia).

${ }^{69}$ Hallinan, 421 P.2d at 87.

${ }^{70}$ See In re Summers, 325 U.S. 561, 571-73 (1945) (affirming the Illinois Supreme Court's rejection of the University of Pennsylvania Law School's beloved Professor Clyde Summers from the bar).

${ }^{71}$ See Strassberg, supra note 23, at 901 (arguing that the "modern articulation of legal ethics as positive law" might "seriously undermine the justification" for engaging in civil disobedience).

${ }^{72}$ Model Code OF Prof'L ResPonsibiLity DR 1-102(A) (3); see also id. EC 1-5 (declaring that attorneys should "refrain from all illegal and morally reprehensible conduct").

MOdel Rules of Prof'L CONDUCT R. 8.4(b). 
their review. It should hardly be surprising, then, that the record of applying the rules provides few definitive answers.

The secondary literature also does little to narrow the range of interpretations of the Model Rules and Model Code. Some commentators argue that the ethics codes obviously prohibit any conscientious disobedience. ${ }^{74}$ Others seem to suggest that one can fairly understand an attorney's professional obligation to permit civil disobedience. ${ }^{75}$ Most acknowledge that the various rules contain ambiguities that allow for considerable "interpretive leeway" on the issue. ${ }^{76}$

Without clear indications of the consequences of conscientious lawyer noncompliance in the codes of ethics, the case law, or the secondary literature, the most honest-and realistic-resolution to the issue is that the disciplinary prosecutors who enforce the rules currently retain enormous discretion as to how to treat civil disobedience. ${ }^{77}$ Though perhaps intellectually unsatisfactory, this conclusion should hardly be surprising. We accept the propriety of prosecutorial

${ }^{74}$ See, e.g., Luban, supra note 22, at 796 (claiming that under the Model Rules, "a lawyer who engages in conscientious disobedience to law is no better than a street criminal, and indeed may be worse if her conscientious disobedience arises from an ideology that is hostile to the American legal system"); Simon, supra note 45, at 424 (noting that there is "no tolerance ... for civil disobedience" in the rules of professional ethics).

${ }^{75}$ See, e.g., Cowen, supra note 2, at 597 (noting that a lawyer could theoretically "stand on the same footing as the nonlawyer" in committing civil disobedience).

${ }^{76}$ Terrell, supra note 28, at 831; see also McMorrow, supra note 38, at 151 ("Both [the Model Rules and Model Code] contain broad ambiguities.").

77 See Strassberg, supra note 23, at 905 ("The actual application of ethical rules suggests a far less rigid construction than might be assumed. Bar associations and state disciplinary institutions ... do not necessarily display the rigid adherence to the limited reach of a rule or specified exceptions which a formalist approach to the rules would dictate."). But cf. Bruce A. Green, Lawyer Discipline: Conscientious Noncompliance, Conscious Avoidance, and Prosecutorial Discretion, 66 FORDHAM L. REV. 1307, 1311 (1998) ("[T] he extent of disciplinary prosecutors' discretion may be especially limited because they lack the independence of criminal prosecutors.”).

Some commentators have noted that the benefits of prosecutorial discretion may be far greater in cases involving attorneys in large firms. See, e.g., Steven France, Can the Bar Regulate the Large Firms?, LEGAL TIMES, Jan. 31, 1994, at 28 (noting that the wide discretion in disciplining prominent attorneys raises serious questions about whether the bar is willing or able to regulate attorneys at large firms, or whether its disciplinary power is directed only at "the occasional stray solo practitioner who pockets money from a client's escrow account”); Susan P. Koniak, Who Gave Lawyers a Pass?, FORBES, Aug. 12, 2002, at 58, 58 (noting that the bar's disciplinary authorities "would be absurdly outgunned" when attempting to discipline attorneys at large firms). This raises important questions about the bar's disciplinary process that are beyond the scope of this Comment. 
discretion in the criminal justice system as a check on unfair laws. ${ }^{78}$ It is certainly possible that the dearth of case law in this area is influenced by prosecutors turning a blind eye to conscientious disobedience. And as Professors Geoffrey Hazard and William Hodes have noted, bar authorities undoubtedly approach attorney civil disobedience with sensitivity to the moral context of the lawbreaking. ${ }^{79}$ In a self-regulated profession in which moral judgment and political independence are prized, ${ }^{80}$ we should expect—and respect—such sensitivity.

Of course, it would be discomforting to any attorney contemplating civil disobedience that her professional fate is left to the discretion of a prosecutor with a moral compass potentially different from her own. Attorneys committing civil disobedience currently risk disciplinary actions that include temporary or permanent disbarment. ${ }^{81}$ It is clear from this discussion that there is some tolerance, though perhaps only unspoken, of the role of civil disobedience by attorneys. ${ }^{82}$ This may be cold comfort, however, given the stakes at play for lawyers.

\section{REFuting THE ARguments AgAinst ATTORNEY CIVIL DISOBEDIENCE}

Critics of attorney civil disobedience note that there is far more at stake when lawyers break the law than simply the consequences for an attorney's career. They argue that noncompliance by the bar has potentially much broader costs to the legal profession, to society, and to the law itself. In their minds, attorney civil disobedience is inappropriate in a legal system that is "generally just, even though not per-

\footnotetext{
${ }^{78}$ See, e.g., Simon, supra note 23, at 226 ("Prosecutorial nullification is widely considered legitimate in circumstances where the application of a statute produces an especially harsh or anomalous result or where an entire statute, usually an old one, seems out of tune with contemporary sentiment ....”).

${ }^{79}$ HAZARD \& HODES, supra note 32, § 9.20 (arguing that it is unlikely that bar authorities would discipline an attorney for violating the rules of ethics to save a life).

${ }^{80}$ See supra text accompanying notes 53-54 (highlighting the ethics rules' emphasis on an attorney's personal conscience); see also Konigsberg v. State Bar of Cal., 353 U.S. 252, 273 (1957) ("It is also important both to society and the bar itself that lawyers be unintimidated-free to think, speak, and act as members of an Independent Bar.”).

${ }^{81}$ See supra note 46 and accompanying text; cf. Luban, supra note 28, at 259 (arguing that the Model Code and Model Rules should be amended to permit lawyers to commit civil disobedience without jeopardizing their licenses).

${ }^{82}$ See supra text accompanying notes 63-69 (discussing the various ways in which the bar has recognized there may be some tolerance of conscientious disobedience by attorneys).
} 
fect." ${ }^{\text {} 33}$ Thus, regardless of whether attorneys can commit civil disobedience under the ethics rules, it remains contested whether they should.

In this section, I will respond to the four major arguments against civil disobedience by analyzing the relationships among the legal profession, the law, and the public. When these relationships are properly understood, it becomes clear that none of these institutions would be threatened by an ethics regime that explicitly tolerated attorney civil disobedience.

\section{A. Attorney Civil Disobedience and Respect for the "Rule of Law"}

The first major objection to attorney disobedience is that it significantly weakens the law's normative power. ${ }^{84}$ Because the law's authority depends in large part on the willingness of individuals in our society to accept and obey it, erosion of respect for the "rule of law" is a serious threat to our legal system. ${ }^{85}$ Critics of attorney disobedience claim that attorney attitudes toward the law "rub off" on nonlawyers. Citizens take cues from attorneys when developing their own sense of obligation to respect the law. Attorneys who disobey the law-even conscientiously-convey to the lay public the potentially dangerous message that the law should be ignored when an individual deems it appropriate to do so.

Related to this claim is the concern that attorney disobedience has a second, more direct effect on the authority of our legal system. While it is deeply problematic for the average citizen not to feel particularly obligated to follow the law, it would be disastrous if the bar had the same lax attitude. ${ }^{87}$ Attorneys are judicial actors whose role is

${ }^{83}$ Terrell, supra note 28 , at 834.

${ }^{84}$ See id. at 835 ("[D]isobedience to the legal and ethical rules of the [legal] system necessarily undermines the system's claim to legitimacy." (emphasis omitted)).

${ }^{85}$ See MURPHY \& COLEMAN, supra note 8, at 29 (stating that a stable legal order requires that the majority of citizens must view the laws "as standards of criticism and justification").

${ }^{86}$ See David B. Wilkins, In Defense of Law and Morality: Why Lawyers Should Have a Prima Facie Duty to Obey the Law, 38 WM. \& MARY L. REv. 269, 292 (1996) ("[T] he attitudes that lawyers convey about the law are likely to rub off on their clients, thereby multiplying the effects of lawyer noncompliance. Even nonclients are likely to pick up important messages about the appropriate moral standing of law from the conduct of lawyers." (footnote omitted)).

${ }^{87}$ See HART, supra note 13, at 116-17 (arguing that judicial actors must accept the internal perspective of the legal system in which they operate); MURPHY \& COLEMAN, 
to implement and interpret the laws. A legal system in which lawyers felt no particular commitment to the rule of law would be ineffective at enforcing social norms and likely unstable. Increasing tolerance for attorney civil disobedience might lead individual attorneys to become overly emboldened to make their own judgments about which laws deserve respect and which ones do not. ${ }^{88}$ This could greatly undermine the consistency and effectiveness of the legal system.

In short, critics charge that attorney lawbreaking "is likely to have larger negative consequences than similar actions" by nonlawyers. ${ }^{89}$ Civil disobedience may be acceptable for citizens, but legal ethics should not lightly tolerate lawyer noncompliance because it significantly undermines our society's respect for the legal system and the rule of law. Such arguments appear to mirror the reasoning of the provisions in the Model Rules and Model Code, which emphasize that "respect for the law should be more than a platitude" for attorneys. Attorneys have a special relationship to the law that gives them a special responsibility to obey it.

Such claims certainly have some merit. One can vividly imagine the injustice of a legal system in which lawyers routinely violate the law themselves. Moreover, the actions of attorneys undoubtedly affect the attitude of others towards the law. Nevertheless, there are several counterarguments to this position-both theoretical and practicalthat significantly undermine its criticism of attorney civil disobedience.

\section{Civil Disobedience Demonstrates Respect for the Law}

The first response to the claim that lawyer noncompliance weakens respect for the law is based on the very nature of civil disobedience. As Dr. Martin Luther King, Jr. wrote in his Letter from Birmingham Jail, "an individual who breaks [a] law that conscience tells him is unjust, and who willingly accepts the penalty of imprisonment in order to arouse the conscience of the community over its injustice, is in reality expressing the highest respect for the law." ${ }^{{ }^{91}}$ By submitting

\footnotetext{
supra note 8 , at 29 (noting the importance of judicial actors respecting the normative power of the law).

${ }^{88}$ Cf. Luban, supra note 22, at 809 (arguing that lawyers may commit civil disobedience because they are "obligated to respect the law only when the law deserves respect").

${ }^{89}$ Wilkins, supra note 86, at 292.

${ }^{90}$ MODEL CODE OF PROF'L RESPONSIBILITY EC 1-5.

${ }^{91}$ KING, supra note 10 , at 83-84.
} 
oneself voluntarily to the legal system's judgment, one recognizes and affirms the law's authority and the legal obligations it imposes, even while protesting its morality. ${ }^{92}$ This aspect of civil disobedience does not change simply because it is a lawyer who commits it.

Civil disobedience puts a choice to the authority figures it challenges: punish the lawbreaker and affirm the value of the rule; disassociate from the system because it is unjust; or acknowledge mistake in the rule and change it. ${ }^{93}$ Far from weakening the law's authority, civil disobedience affords the state an opportunity to strengthen its normative power. In response to conscientious lawbreaking, the legal system reevaluates the rule that was violated, struggles with the moral issues it implicates, and strengthens the legal obligation imposed by affirming the law and punishing the lawbreaker. It is true that a judicial pronouncement radically out of line with a society's common morality may undermine the public's sense that the law in question is just and deserving of respect, but this is in no way exacerbated by the fact that the lawbreaker is an attorney.

${ }^{92}$ See Leubsdorf, supra note 4, at 938-39 (describing the respect with which Gandhi submitted himself to the law's judgment as an important part of his philosophy). In contrast, David Luban has argued for what I believe is a more radical view of civil disobedience. He claims that citizens and lawyers are "obligated to respect the law only when the law deserves respect." Luban, supra note 22, at 809. "When the law is evil, unfair, or hopelessly stupid ... the obligation [to obey it] vanishes and disobedience is in order." LUBAN, supra note 37 , at 35 . While such rhetoric is similar to that of traditional civil disobedience, it differs significantly by opening the door to the claim that immoral laws impose no legal obligation on citizens. Luban's position all but collapses the distinction between moral and legal obligation. See Luban, supra note 22, at 809 (suggesting that the "ground of [legal] obligation lies in some morally relevant property of laws").

This approach is much closer to the traditional natural law perspective-i.e., that an unjust law is not a valid law-than it is to my operative conception of civil disobedience, under which one recognizes a valid legal obligation that is simply trumped by a competing moral duty. See id. at 801-02 (arguing that the law implies a "utopian ideal" and acknowledging the similarity between his position and natural law); $i d$. at 806 (stating that lawyers should consider the "natural-law legality" of a contested law when considering whether to take a case). The understanding of civil disobedience I have in mind here, however, is decidedly not based on natural law. By willingly accepting punishment from the legal system, a conscientious objector recognizes a law's legal validity and separates her moral obligations from her legal ones. Such a separation has a strong positivist flavor to it, in spite of the moral protest involved. See HART, supra note 13, at 210 (arguing that morally iniquitous laws may still be valid, but that the legal obligations they impose can be overcome by nonlegal, moral inquiry).

${ }^{93}$ See Freedman, supra note 2, at 1137 (explaining how the author's civil disobedience forced the bar to change an ethics rule); Leubsdorf, supra note 4, at 932 (recounting Gandhi's statement that a judge must either inflict punishment on the lawbreaker or disassociate from the "evil" law at issue). 
An example of the opportunity conscientious lawbreaking offers to strengthen legal obligation is provided by the case of Alabama Supreme Court Chief Justice Roy Moore, who defied a federal injunction that ordered him to remove a monument of the Ten Commandments he had placed at the courthouse. ${ }^{94}$ While there are unique aspects of Moore's case that distinguish it from the typical conscientious disobedience, ${ }^{95}$ the matter is fairly comparable to attorney civil disobedience for the purposes of evaluating its effect on public respect for the law. In both cases, the defiance is public, based on a moral objection to the law, and committed by a judicial actor.

Chief Justice Moore's defiance provided the federal and state judiciaries with the opportunity to strengthen the rule of law. The federal judiciary affirmed the importance of the First Amendment's protection of separation of church and state, and the Alabama state judiciary reinforced the principle that " $[\mathrm{n}] \mathrm{o}$ man in this country is so high that he is above the law." ${ }^{, 96}$ Regardless of one's moral views about Moore's actions, the incident left no doubt as to his legal obligations under the First Amendment. As one might expect in a pluralistic society, Moore had strong supporters whose respect for the law and sense of duty to it was shaken by the incident. ${ }^{97}$ But for other citizens,

${ }^{94}$ See Pryor, supra note 2, at 1 ("On August 14, 2003, Chief Justice Roy Moore announced that he would not obey an injunction of the U.S. District Court for the Middle District of Alabama to remove a monument with a depiction of the Ten Commandments from the rotunda of the State Judicial Building." (footnote omitted)); see also Stan Bailey, Moore Kicked Off State's High Court: 'No Man . . Is So High as to Be Above the Law,' Court Rules, Birmingham News, Nov. 14, 2003, at A1 (describing the consequences of Justice Moore's defiance of the federal injunction).

${ }^{95}$ For starters, there is a genuine question as to whether or not Chief Justice Moore's defiance actually qualifies as justified civil disobedience. See Pryor, supra note 2, at 2 n.7 (noting that Moore himself was equivocal about whether his actions constituted justified civil disobedience); Anthony J. Sebok, Ten Commandments Defiance Doesn't Meet Civil Disobedience Test, CNN.COM, Aug. 26, 2003 (arguing that Moore's defiance was not justified civil disobedience), available at http://www.cnn.com/ 2003/LAW/08/26/findlaw.analysis.sebok.commandments. In addition, Moore's position as a judge distinguishes his disobedience from that of a private citizen. See Pryor, supra note 2, at 8 (observing that Moore's moral position was different from Dr. Martin Luther King, Jr.'s in part because Moore was a public official); Sebok, supra (arguing that Moore had a "special obligation to obey the law and to obey duly adjudicated interpretations of the law" because he was a judge).

${ }^{96}$ In $r$ Moore, No. 33, slip op. at 9 (Ala. Ct. of the Judiciary Nov. 13, 2003) (quoting United States v. Lee, 106 U.S. 196, 220 (1882)), available at http:// www.judicial.state.al.us/documents/final.pdf, aff'd, Moore v. Judicial Inquiry Comm'n, No. 1030398, 2004 WL 922668 (Ala. Apr. 30, 2004).

${ }^{97}$ See Pryor, supra note 2, at 2 (referring to Moore's supporters); Bailey, supra note 94 (describing the support Moore received even after his punishment by the Alabama Court of the Judiciary). 
particularly those who take their cues about the law's validity and worthiness from the judicial system itself, the lesson of Moore's defiance was that he violated a fundamental principle of our society and that the judicial system responded by disciplining him accordingly. The law functioned fairly and efficiently, dealing with Moore as it would have another lawbreaker without his considerable official stature. Surely this was a victory for the rule of law, not a defeat.

\section{The Double Standard for Judging Attorney Civil Disobedience and Routine Legal Practices}

There is something particularly hollow about the claim that attorney civil disobedience weakens respect for the law in light of many common practices that we expect and encourage in the name of "zealous representation." As a matter of course in their daily work, lawyers seek to utilize the law to the advantage of their clients, often at the expense of the public good, a law's clear purpose, or the interest of justice. $^{99}$ Attorneys exploit loopholes in the tax code, ${ }^{100}$ structure transactions to avoid pesky regulations, ${ }^{101}$ and argue for far-fetched constructions of the law to further client interests. ${ }^{102}$ After the collapse of Enron, the public learned that it was "routine" (though per-

98 See Model Code of Prof'L Responsibility Canon 7 (“A Lawyer Should Represent a Client Zealously Within the Bounds of the Law").

${ }_{99}$ See Robert W. Gordon, The Independence of Lawyers, 68 B.U. L. REV. 1, 10 (1988) (noting that lawyers "are expected and even encouraged to exploit every loophole in the rules, take advantage of every one of their opponents' tactical mistakes or oversights, and stretch every legal or factual interpretation to favor their clients"); Stephen F. Smith, Cultural Change and "Catholic Lawyers," 1 AVE MARIA L. REV. 31, 48 (2003) ("'[J] ustice' to the contemporary lawyer is whatever his client wants to achieve and nothing more." (emphasis omitted)); Mike France, Commentary, Close the Lawyer Loophole, BUS. WK., Feb. 2, 2004, at 70, 70 (characterizing attorney advice on risky tax shelters as a "get-out-of-jail-free card" for clients).

${ }^{100}$ See George Cooper ed., The Avoidance Dynamic: A Tale of Tax Planning, Tax Ethics, and Tax Reform, 80 Colum. L. REV. 1553, 1555-60 (1980) (recounting a debate about the ethics of aggressive representation and "tax avoidance"); David B. Wilkins, Legal Realism for Lawyers, 104 HARV. L. REV. 468, 520-21 (1990) (describing the practice of tax attorneys giving clients advice that furthers client interests, regardless of whether the advice is contrary to the public purpose of the tax code).

${ }^{101}$ See Deborah L. Rhode \& Paul D. Paton, Lawyers, Ethics, and Enron, 8 STAN. J. L. BUS. \& FIN. 9, 17-24 (2002) (describing the role of attorneys in structuring the transactions that later forced Enron into bankruptcy); see also Koniak, supra note 77, at 58 ("[W]ithout lawyers few scandals would exist, and fewer still would last long enough to cause any real harm.").

102 See Model Code OF Prof'L ResPonsibility EC 7-4 (permitting attorneys to argue in favor of any construction of the law, without regard "to the likelihood that the construction will ultimately prevail"). 
haps not legal) for lawyers to give advice that would have the effect of frustrating federal investigations. ${ }^{103}$ A century ago, future Justice Louis Brandeis noted that it increasingly seemed to be the project of attorneys to "evade or nullify the extremely crude laws by which legislators sought to regulate the power or curb the excesses of corporations."

The messages sent by the legal profession through such representation are clear: a client's interest supercedes the public interest; the law is vulnerable to seemingly endless manipulation; even the clearest of legal duties is subject to debate. ${ }^{105}$ The effect of such messages, conveyed to the public by nearly every aspect of the modern legal profession, is unquestionably significant to our society's attitude towards the law. Lawyers who stretch the fabric of the law to its breaking point while representing clients seek to reshape the applicability of a legal duty to fit their client's interests, which may overlap with the public good-but only coincidentally. ${ }^{106}$ Such representation strips the law of its veneer of generality, the characteristic that is most critical to our society's internal sense of obligation to the law. ${ }^{107}$ Such a pervasive attitude in the legal profession must weaken our society's respect for the rule of law at least as much as it is purportedly weakened by attorney civil disobedience, by which lawyers demonstrate their devotion to the

103 See Rhode \& Paton, supra note 101, at 24 (describing the profession's reaction to the actions of Nancy Temple, the in-house Arthur Andersen attorney whose advice during the Enron affair eventually helped lead to the firm's downfall).

${ }^{104}$ Louis D. Brandeis, The Opportunity in the Law, Address to the Harvard Ethical Society (May 4, 1905), in BRANDEIS ON DEMOCRACY 52, 57 (Philippa Strum ed., 1995).

${ }^{105}$ These attitudes are central to an attorney's education during law school. As one commentator noted of his own law school experience:

Legal writing was ... the assembly of new, partisan structures from the various components discovered in the process of deconstructing relevant cases. It didn't matter, apparently, that these new structures were routinely built of blocks intended for entirely different purposes, that ill-fitting components were mangled or left out, that the completed structure often served the lawyer's purposes as much as his client's. The point was to create a building that looked better than one's opponents' ... even if it was just a house of cards.

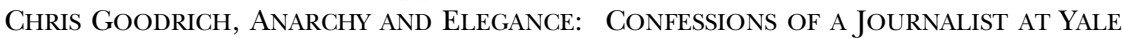
LAW SCHOOL 95 (1991); see also Robert Granfield \& Thomas Koenig, "It's Hard to be a Human Being and a Lawyer": Young Attorneys and the Confrontation with Ethical Ambiguity in Legal Practice, 105 W. VA. L. REV. 495, 501 (2003) ("Law school teaches students to become tough-minded, hyper-rational, and insensitive to issues beyond the interests of their client-a perspective that undermines ethical decision-making.").

${ }^{106}$ See Pepper, supra note 37, at 1554 (arguing that the legal profession's approach to the law "may lead the client to respect the law less").

${ }^{107}$ See LUBAN, supra note 37, at 48-49 ("[T] he principle of partisanship in the legal profession threatens to undermine the generality of law and thus to abrogate the moral authority of law. It is only its generality, its fairness, that elevates law from a coercive system to a system exerting moral—and not just physical—force."). 
public interest and affirm the legal authority of the law by willingly accepting punishment.

Critics of lawyer civil disobedience seem to apply two sets of rules to attorney actions that affect respect for the law. They fear the effect of morally motivated noncompliance by attorneys, but defend a model of the profession that sacrifices respect for the generality of law to a client's interests. This apparent inconsistency is not merely a product of applying different standards to attorney actions taken while representing a client than to actions taken in one's individual capacity. ${ }^{108}$ For example, in the context of criticizing attorney disobedience, Professor Timothy Terrell also condemns the development of a "duty-based" practice of law, which emphasizes society's interests over those of one's clients. ${ }^{109}$ Terrell cites several examples of the trend toward duty-based lawyering that he finds particularly troubling, including recent strategies to hold attorneys accountable for their role in questionable transactions within the healthcare industry, as well as the Sarbanes-Oxley Act's requirement that attorneys breach confidentiality to prevent securities fraud. ${ }^{110}$ Whatever one thinks about the merit of these attempted reforms of the legal profession, it is clear that they were intended to rehabilitate our society's respect for and trust in the law after instances in which attorneys' advocacy for their clients seemed to go too far. ${ }^{111}$ Thus, Terrell's criticism of these changes, juxtaposed with his fear that attorney civil disobedience will weaken respect for the law, ${ }^{112}$ is perplexing.

I should not be misunderstood as taking a position directly on the question of whether it is proper for attorneys to engage in so-called "aggressive lawyering" in their clients' interests. There are strong arguments that keeping the interests of clients at the center of attorney advocacy helps the law to evolve and improve for the benefit of society. It is a model that protects a client's autonomy and provides a check on the power of the state. ${ }^{13}$ My critique is limited to noting the

${ }^{108}$ See Terrell, supra note 28, at 847 (defining attorney civil disobedience to include violations of ethics rules committed to protect a client's interests).

${ }^{109}$ See id. (stating that a duty-based practice of law would fundamentally change the legal profession).

${ }^{110}$ See id. at 848-51 (listing examples of duty-based lawyering).

${ }^{111}$ See id. at 850 (finding that the Sarbanes-Oxley provision was enacted to strengthen investor confidence and trust in the securities laws).

${ }^{112}$ See supra note 84.

113 See, e.g., Stephen Ellmann, Lawyering for Justice in a Flawed Democracy, 90 CoLum. L. REV. 116, 176-81 (1990) (reviewing LUBAN, supra note 37) (arguing that Luban's 
inconsistency of those who claim that attorney civil disobedience is flawed because it weakens respect for the law while simultaneously defending routine practices of lawyers that likely have a more adverse effect on the rule of law. Civil disobedience and aggressive lawyering implicate the same interests: improvement of the law and resistance to the state's potential for injustice. These goals either outweigh the need for attorneys to protect the public's respect for the law, or they do not. If they do, however, they should do so in both contexts.

\section{The Inconsistent Position of the Organized Bar on Attorney Civil Disobedience}

Past actions by the organized bar cast doubt on how seriously one should take its insistence in the Model Rules and Model Code that attorneys display an almost sacred respect for the law. ${ }^{114}$ When it comes to the law governing lawyers, the bar has demonstrated far less respect for the law than one might assume based on its pronouncements in the codes of ethics. According to Professor Susan Koniak, the bar has "flouted and bypassed court attempts to articulate the law governing lawyers ... [and] used its own power to insist on a law that diverges from the 'official' law articulated by the courts." 115 In so doing, the bar has suggested that respect for the state's law appropriately takes a back seat to other considerations in certain instances.

At various times in recent history, the bar has asserted its claim to self-regulation when threatened with increased government oversight. ${ }^{116}$ On occasions when the government has regulated lawyers over the objections of the legal profession, the bar has directly resisted the new rules. When state courts began to require attorneys to violate traditional rules of client confidentiality to prevent fraud, the ABA-rather than accept and respect the determination of the judiciary-insisted that the profession was under no such obligation. ${ }^{117}$ The bar's resis-

proposal to restrict the partisanship of lawyers when such partisanship violates common morality would severely interfere with client autonomy).

${ }^{114}$ See supra text accompanying notes 39-46 (describing the strong emphasis in the Model Rules and Model Code that attorneys demonstrate respect for the law).

${ }^{115}$ Susan P. Koniak, When Courts Refuse to Frame the Law and Others Frame It to Their Will, 66 S. CAL. L. REV. 1075, 1092 (1993).

${ }^{116}$ See Koniak, supra note 77, at 58 ("Twice in its history [the SEC] had gotten serious about regulating the bar. Both times the bar beat the agency back."); Koniak, supra note 115, at 1091 (describing the reaction of the bar to the government's prosecution, in the early 1990s, of the law firm Kaye Scholer for its participation in the Lincoln Savings and Loan scandal).

${ }^{117}$ See Koniak, supra note 115, at 1094-96 (describing the bar's extensive struggle 
tance included an acknowledgement that "lawyers may (and perhaps even should) refuse to comply with lower court orders requiring disclosure of information that the lawyer believes to be confidential, even in circumstances in which the clear weight of legal authority mandates disclosure." 118 In 1989, when the IRS requested attorneys to report cash payments in excess of $\$ 10,000$, “[ $t$ ] he vast majority of lawyers receiving the IRS demand letter refused to comply." 119 No cry issued in response from the organized bar about the importance of respecting the rule of law; far from it. In fact, bar leaders encouraged attorneys to continue their resistance. ${ }^{120}$

In other words, notwithstanding the lofty rhetoric in the Model Code and Model Rules that " $[\mathrm{t}] \mathrm{o}$ lawyers ... respect for the law should be more than a platitude," ${ }^{121}$ the bar has supported attorney civil disobedience. Certainly this cannot, and should not, be taken as a general endorsement of noncompliance by the ABA. It should, however, give us some perspective about the consequences of lawyer disobedience on our society. In real-world applications of the ethics rules, even the organized bar has recognized that there are some extralegal principles that outweigh an attorney's legal duty and her professional responsibility to demonstrate respect for the law. While it is conceivable that the bar views the rule of client confidentiality as the only principle for which it is worth an attorney breaking the law, it is more reasonable to believe that there are competing moral precepts of greater worth for which civil disobedience is also justified. ${ }^{122}$

with state courts over the issue of disclosure of confidential information).

${ }^{118}$ Wilkins, supra note 86, at 276-77; see also Koniak, supra note 115, at 1102 ("Ethics opinions advising lawyers what to do when faced with state law that appears to require disclosure or some other infidelity to the client suggest that a lawyer is free to ignore the weight of court authority.").

${ }^{119}$ Susan P. Koniak, The Law Between the Bar and the State, 70 N.C. L. REv. 1389, 1405 (1992).

${ }^{120}$ See id. at 1406-07 (describing the reactions of leaders of the state and national bar associations to the attorney noncompliance); Wilkins, supra note 86, at 277 (“[B]ar leaders continue to urge lawyers to defy an IRS regulation requiring lawyers to report cash payments by clients above a certain amount.").

${ }^{121}$ MODEL CODE OF PROF'L RESPONSIBILITY EC 1-5.

122 See HAZARD \& HODES, supra note $32, \S 9.20$ (arguing that a lawyer would be justified in violating client confidentiality in order to save a life). 


\section{Isolated Acts of Attorney Civil Disobedience \\ Do Not Threaten the Rule of Law}

A final common-sense response to the claim that attorney civil disobedience will erode respect for the law is that any adverse impact on the rule of law from a lawyer's isolated act of noncompliance will be minor. ${ }^{123}$ Any negative impact on the public would very likely remain localized for the simple reason that it would be rare for the disobedience to be publicized more widely. ${ }^{124}$ Moreover, attorney civil disobedience is almost certain to remain relatively isolated. While nearly every lawyer recognizes flaws in the legal system, few lawyers question the law's legitimacy so deeply that they would resort to noncompliance on more than a rare occasion. ${ }^{125}$ Evidence indicates that many attorneys hold views similar to those of their privileged clients-hardly the citizens from whom one expects widespread civil disobedience. ${ }^{126}$ One survey reported that only about one in every six attorneys in large firms had ever refused an assignment or potential work solely because it violated her personal values. ${ }^{127}$ Such empirical evidence about the attitudes of attorneys strongly suggests that a codified ethical acknowledgement that some moral obligations may trump an attorney's duty to respect the law will not open the floodgates to widespread attorney civil disobedience.

${ }^{123}$ See Wilkins, supra note 100, at 511 ("An isolated act of lawyer nullification does not threaten the rule of law.").

${ }^{124}$ See Fred C. Zacharias, The Lawyer as Conscientious Objector, 54 RUTGERS L. REV. 191, 212 n.85 (2001) ("Although lawyer 'misconduct' often is publicized in the press, the lawyer's notoriety typically is limited to the local jurisdiction. The systemic effects of the lawyer's conduct will probably be similarly confined."). There are, of course, exceptions to the general thesis that attorney civil disobedience receives only local attention. Cf. supra text accompanying notes 94-97 (discussing the case of Alabama Chief Justice Roy Moore).

${ }^{125}$ See Kathryn Abrams, Lawyers and Social Change Lawbreaking: Confronting a Plural Bar, 52 U. PITT. L. REV. 753, 778 (1991) (noting that many lawyers do not "question the legitimacy of the legal system," and that even those who do so do not widely resort to civil disobedience).

${ }^{126}$ See Wilkins, supra note 100, at 513 ("Empirical evidence indicates that many lawyers-particularly those representing the powerful-hold views about legal merit that strikingly resemble the interests of their clients."). But see Abrams, supra note 125, at 761-66 (arguing that attorneys who represent oppressed or powerless clients are less likely to view the legal system as wholly legitimate).

${ }^{127}$ Robert L. Nelson, Ideology, Practice, and Professional Autonomy: Social Values and Client Relationships in the Large Law Firm, 37 STAN. L. REV. 503, 534-35 (1985). 


\section{B. Attorney Civil Disobedience and Respect for Lawyers}

The second major argument commonly offered against attorney civil disobedience is that it reduces the public's respect for the legal profession. Given that our society generally assumes all citizens have a duty to follow the law, attorney civil disobedience may reflect negatively on lawyers generally. The public may trust lawyers less, for fear that they have their own agenda and that their professional ethics are inadequate. ${ }^{128}$ Nonlawyers may perceive attorney noncompliance to be symptomatic of a double standard in the legal profession, whereby lawyers, while ostensibly counseling others to obey the law, feel at liberty to disobey it themselves.

Reducing the public's trust in the legal profession has worrisome implications for client service, as well as for the legal system as a whole. Lawyers enjoy power and privileges that are contingent on maintaining the public's trust in the profession. A lawyer's ability to conceal information under attorney-client confidentiality that other citizens would be required to disclose is just one example of such a privilege. For the profession to continue justifying such special treatment, society must believe that attorneys are people of integrity. ${ }^{129}$ In addition, as trust of lawyers erodes, the legal system becomes more unstable. Clients must depend on attorneys to honor their duty of zealous representation; ${ }^{130}$ judges must rely on lawyers to act as upright "officers of the court" who will play fair while serving their clients. The judicial process depends on the trust that all sides place in attorneys to uphold their duties. Thus, the charge that lawyer civil disobedience weakens respect for the legal profession is a serious concern.

As an initial matter, it should be noted that our society hardly seems to hold lawyers in high esteem today. A brief survey of the

${ }^{128}$ See Zacharias, supra note 124, at 211-13 (describing the potential impact of attorney defiance on the public's perception of the legal profession).

${ }^{129}$ See France, supra note 99, at 70 (relating the character requirements for attorneys to their extensive power in the legal system). In addition, Professor Timothy Terrell has argued that "[i]f and only if the rule of law has a normative foundation does the 'role' a lawyer plays as a professional have any moral standing." Terrell, supra note 28 , at 834 . Thus, by undermining the public's sense of duty to obey the law through their acts of civil disobedience, Terrell believes that attorneys weaken the very aspect of the law that gives them their unique power in the legal system.

${ }^{130}$ See MOdel CODE OF Prof'L Responsibility EC 7-1 ("The duty of a lawyer, both to his client and to the legal system, is to represent his client zealously within the bounds of the law...." (footnotes omitted)). 
genre of "lawyer jokes" provides a fairly strong indication of this fact. ${ }^{131}$ Consider just a small sampling:

Question: Why did the research scientist substitute lawyers for rats in his laboratory experiments?

Answer: Lawyers breed more rapidly, scientists became less attached to them, and there are some things that rats just won't do. ${ }^{132}$

$\mathrm{Q}$ [uestion]: What is the difference between a catfish and a lawyer?

$\mathrm{A}[$ nswer]: One is a disgusting, bottom-feeding scavenger, and the other is just a fish. ${ }^{133}$

More methodically gathered evidence confirms that the public has a negative view of lawyers. In a recent public opinion poll, eighteen percent of respondents believed that attorneys had high ethical standards. Lawyers were positioned near the bottom of professions in this category, ranking above the likes of car salesmen and advertising practitioners but below Congressmen. ${ }^{134}$ In another survey, only about one in every four people said they trusted lawyers to tell the truth, positioning them nineteenth out of the twenty professions considered. ${ }^{135}$

While negative social views of the legal profession are hardly novel, ${ }^{136}$ the recent highly publicized corporate scandals have further tarnished the image of attorneys. ${ }^{137}$ Lawyers played key roles in the Enron, Tyco, and Global Crossing affairs. ${ }^{138}$ As legal ethics expert Stephen Gillers has noted, whereas lawyers would ideally serve as "brakes

${ }^{131}$ For a survey of this comedic craft, start with Lawyer Jokes, at http://www.ahajokes.com/lawyer_jokes.html (last visited Dec. 31, 2004); Lawyer Jokes and Cartoons, at http://www.lawyer-jokes.us (last visited Dec. 31, 2004); and http:// www.lawyerjokes101.com (last visited Dec. 31, 2004).

${ }_{132}$ Robert C. Post, On the Popular Image of the Lawyer: Reflections in a Dark Glass, 75 CAL. L. REV. 379, 379 (1987).

${ }^{133}$ Smith, supra note 99 , at 49.

134 Gallup Poll, Nov. 19-21, 2004, available at http://www.pollingreport.com/ values.htm (last visited Dec. 31, 2004).

${ }^{135}$ The Harris Poll, Nov. 14-18, 2002, available at http://www.pollingreport.com/ workplay.htm (last visited Dec. 31, 2004).

${ }^{136}$ See, e.g., LAWrence M. Friedman, A History OF AMERICAN LAW 94-96 (2d ed. 1985) (noting that distrust and resentment of lawyers dates back to colonial times, perpetuating ancient English prejudice); WILliAM SHAKESPEARE, THE SECOND PART OF KING HENRY THE SIXTH act 4, sc. 2 ("The first thing we do, let's kill all the lawyers.").

${ }^{137}$ See Smith, supra note 99, at 48 ("The image of lawyers reached new lows with the wave of corporate scandals that shook Wall Street in 2002.").

${ }^{138}$ See id. at 48-49 (describing the involvement of lawyers in the Enron and Tyco scandals); Koniak, supra note 77, at 58 (noting that Simpson Thacher \& Bartlett's investigation of a whistle-blower memo about Global Crossing was "even worse than that by Vinson \& Elkins of the Sherron Watkins/Enron memo"). 
on bad conduct," the reality is that "client pressures have turned [lawyers] into more of a gas pedal.",139

One might argue that the prevalence of such bleak views about attorneys lends support to the claim that lawyer civil disobedience would be harmful to the profession. If the bar is on the brink of losing the public's confidence altogether, the last thing we want is the public to see attorneys flouting the authority of the law. This conclusion is flawed. It overlooks the reasons for the bar's scarred image and, consequently, misunderstands the effect of civil disobedience on the profession.

Evidence suggests that the two ideas that most contribute to the negative view of attorneys are the impression that they are moneyhungry and the belief that they "manipulate the legal system without any concern for right or wrong." today's lawyer "all too often strives only to be 'aggressive' ... not in the pursuit of justice but only in the prurient, self-serving interests of his or her own clients." ${ }^{\text {141 }}$ It is hard to imagine how publicity of a lawyer taking a deeply held moral stand, while willingly accepting the legal system's punishment, would add to these negative images of the profession. On the contrary, such actions display the characteristics that the public seems to believe are lacking among lawyers: selfsacrifice, concern for the public interest, and recognition of the rule of law.

It is significant that among our culture's most revered images of lawyers are those who protect justice over rigid and impersonal rules and preserve moral integrity over personal interests. Atticus Finch, perhaps the most dignified lawyer in our shared cultural memory, agrees at the conclusion of To Kill a Mockingbird to lie to the town about the circumstances of Bob Ewell's death-that is, to obstruct jus-

${ }^{139}$ Mike France, What About the Lawyers?, Bus. WK., Dec. 23, 2002, at 58, 59 (quoting Professor Gillers's discussion of whether the SEC's new regulations on lawyers go far enough), available at http://www.businessweek.com/print/magazine/content/02_51/ b3813093.htm (last visited Dec. 31, 2004).

${ }^{140}$ Post, supra note 132, at 380 (noting that $32 \%$ of respondents to a 1986 National Law Journal poll thought that the most negative aspect of lawyers was their interest in money, and $22 \%$ believed it was their exploitation of the legal system); see also Catherine Crier, The Case Against LaWYers: How LaWyers, Politicians, and BUREAUCRATS HAVE TURNED THE LAW INTO AN INSTRUMENT OF TYRANNY-AND WHAT We as Citizens Have to Do About It 180-98 (2002) (describing how attorneys use money to influence the legal and political system, in order for them to make more money).

${ }^{141}$ Smith, supra note 99 , at $47-48$. 
tice-in order to protect the innocent Boo Radley. ${ }^{142}$ John Grisham's lawyer-heroes often violate professional ethics to achieve justice. ${ }^{143}$ On television's The Practice, the attorneys repeatedly demonstrate what William Simon calls "moral pluck," which often requires them to ignore their legal or ethical duties in the interest of what is right. ${ }^{144}$ Such characters have in common an element of rebelliousness, generally revealed by their willingness to bend or break the strict edicts of the law to arrive at the just result. If popularity is any indication, their defiance of the law seems to have earned such attorneys our admiration, not condemnation. ${ }^{145}$

Of course, life is not a movie, and I do not argue based on fictional works that attorney civil disobedience would actually improve the public's respect for the legal profession. I merely claim that it is highly unlikely that our society would condemn lawyers who commit civil disobedience because they display precisely the virtues that the public seems to want the bar to internalize. We must recognize that, to some extent, the legal profession is in a no-win situation when it comes to public respect. In an adversarial legal system, in which individuals rely on lawyers to protect their rights, attorneys are both loved and reviled for the very same thing: strong advocacy of their client's interests. $^{146}$ We hate the fact that, in the words of Vito Corleone, "[1] awyers can steal more money with a briefcase than a thousand men with guns and masks," "stealing" on our behalf. Attorney civil disobedience would not affect this dynamic one way or another because it appeals to the best view of lawyers as protectors of justice and virtue, especially when it comes

${ }^{142}$ HARPER Lee, To KILl A MOCKINGBIRD 274-79 (1960); see also Simon, supra note 45, at 421-22 (characterizing Atticus Finch's actions as obstruction of justice, but noting that it is clear to the audience that Atticus has "do[ne] the right thing").

${ }^{143}$ See Simon, supra note 45, at 425-29 (discussing the prototypical role of ethics violations in John Grisham's novels).

${ }^{144}$ See id. at 435-40 (describing the complicated role that morality plays in the television series).

${ }^{145}$ See, e.g., CRIER, supra note 140 (dedicating her book to Henry Drummond, from Inherit the Wind, and Atticus Finch, from To Kill a Mockingbird); Simon, supra note 45, at 437-38 (describing a scenario on The Practice in which an attorney flouts professional responsibility norms and noting that "most of us" probably sympathize with and admire him for it).

${ }^{146}$ See Post, supra note 132, at 380 (" $[\mathrm{L}]$ awyers are applauded for following their clients' wishes and bending the rules to satisfy those wishes; and they are at the very same time condemned for... using the legal system to get what their clients want, rather than to uphold the right and denounce the wrong.").

${ }^{147}$ MARIo PUZO, THE GOdFATHer 220 (1969). 
outside of the client context. Some official tolerance for lawyer noncompliance might not improve the public's respect for the profession, but it would not weaken it either.

\section{Attorney Civil Disobedience and the Bar's Voluntary Promissory Obligation}

The third argument against attorney civil disobedience is that lawyers have voluntarily agreed to obey the law by choosing their profession and agreeing to its ethical norms. ${ }^{148}$ This contractarian perspective of a lawyer's duty to the law holds that, even though other citizens have a right to commit civil disobedience, attorneys have a heightened duty to obey the law by virtue of their conscious decision to become lawyers. ${ }^{149}$ When attorneys promise to uphold and obey the law, they impose on themselves an additional moral duty that is distinct from every citizen's obligation to uphold the rules of the state. In essence, this argument claims that attorneys freely forsake the option of future civil disobedience the moment they take their oaths for the bar.

The emphasis on the legal profession's promissory obligation to obey the law is inimical to the traditional concept of an independent bar capable of making free moral and political judgments. ${ }^{150}$ The Supreme Court noted more than forty-five years ago that a "bar composed of lawyers of good character is a worthy objective but it is unnecessary to sacrifice vital freedoms in order to obtain that goal." ${ }^{151}$ The freedom to judge, criticize, and resist the state's authority is not taken from lawyers by their choice of profession. ${ }^{152}$

${ }^{148}$ See Wilkins, supra note 86, at 290 (“[U]nlike ordinary citizens, lawyers have expressly promised to obey the law. ... By expressly undertaking this commitment, lawyers have entered into a voluntary agreement with society that, like any other promise, has independent moral weight."); see also McMorrow, supra note 38, at 142 (noting that state bars "may compel a bar applicant to take an oath of office," which likely includes a promise to uphold the law).

${ }^{149}$ See Terrell, supra note 28, at 846 ("Lawyers voluntarily join an association that imposes duties on them.").

${ }^{150}$ See Konigsberg v. State Bar of Cal., 353 U.S. 252, 273 (1957) ("It is also important both to society and the bar itself that lawyers be unintimidated-free to think, speak, and act as members of an Independent Bar.").

${ }^{151}$ Id

${ }^{152}$ See id. (noting that lawyers must remain "unintimidated," with the freedom to act on independent moral and political judgments); see also In re Sawyer, 360 U.S. 622, 631 (1959) ("We start with the proposition that lawyers are free to criticize the state of the law."). 
There are compelling reasons to be wary of encroaching on the bar's independence. Attorneys are among the primary judicial actors who interpret and implement the law. Their ability to make autonomous moral assessments of the law and publicly protest an immoral rule is a critical check on injustice in our legal system. The acquiescence of the legal profession to the tragedies of Nazi Germany vividly illustrates this point. ${ }^{153}$ In the aftermath of World War II, scholars considered how the German legal community had "easily succumbed as a willing tool of the Nazis." ${ }^{154}$ While no consensus emerged about the cause for the lack of resistance, it was clear that the profession as a whole had prioritized its legal duty to the state more highly than its moral obligations, to an appalling end. ${ }^{155}$ This remains a powerful example of the dangerous potential that emerges by stripping the bar of its ability and willingness to resist the state.

The concept of an independent bar presupposes that attorneys do not forfeit all of their freedom to engage in conscientious disobedience simply by joining the bar. ${ }^{156}$ Lawyers cannot possibly predict every moral problem they will encounter later in practice at the time they take their oaths. ${ }^{157}$ The concept of an independent legal profession would be meaningless if it applied only at the moment an attorney takes an oath, but was negated by that oath. The purpose of an independent bar is to provide ongoing vigilance against

153 See Simon, supra note 23, at 224 (discussing the dangers to a society when lawyers pledge "compliance with jurisdictionally adequate but morally evil laws like the Nazi enactments requiring reporting Jews and dissidents").

${ }^{154}$ Strassberg, supra note 23 , at 917.

${ }^{155}$ See id. at 917-18 (describing the debates among scholars over the role of legal positivism in Nazi Germany).

${ }^{156}$ See Zacharias, supra note 124, at 202 n.56 (arguing that attorneys do not forsake their right to conscientiously disobey the law when they join the bar).

${ }^{157} I d$. There is an argument to be made, based on contract law, that a lawyer may be released from her oath to obey the law in cases where the state of the law frustrates the lawyer's principal purpose of working for justice. See Krell v. Henry, 2 K.B. 740, 748 (Eng. C.A. 1903) (releasing defendant from his obligations under a contract which had its basic purpose frustrated prior to performance); RESTATEMENT (SECOND) OF CONTRACTS $\$ 265$ (1979) (stating the principle of discharge by supervening frustration); supra notes 47-49 and accompanying text (outlining the obligation in the ethics rules to make the law more just). It is unclear, however, that this argument would have much traction in light of the competing principle of assignment of risk in long-term contracts for foreseeable events. See N. Ind. Pub. Serv. Co. v. Carbon County Coal Co., 799 F.2d 265, 278 (7th Cir. 1986) (stating that the frustration of purpose defense is improper where the parties have assigned the burden of risk in a contract); Lloyd $\mathrm{v}$. Murphy, 153 P.2d 47, 50 (Cal. 1944) (holding that the risk of a frustrating event that is reasonably foreseeable is assumed and cannot be grounds for a frustration of purpose defense). 
future injustice. Lawyers must make moral judgments about the law as it changes, not as it was when they agreed to uphold it in their oath.

Professor Freedman notes that an attorney remains "a free person, with moral responsibility," despite taking the oath for admission to the bar. ${ }^{158}$ Attorneys unavoidably assume a measure of moral responsibility for the substantive outcomes of the law because they "exercise quasi-legislative power in deciding whether a given legal command applies to a particular case."159 Given this responsibility, it is reasonable to expect that the concept of attorney independence would also give attorneys some autonomy over the decision to resist an unjust law. ${ }^{160}$ Civil disobedience is an accepted form of protest by other citizens and a critical tool for attorneys to prevent injustice that is not removed by an oath. ${ }^{161}$ The voluntary decision to join the bar cannot alone strip lawyers of this freedom.

\section{Attorney Civil Disobedience and the Bar's Privileged Position}

The final argument against attorney civil disobedience is based on the fact that lawyers enjoy far more power within the legal system than other citizens. Some critics of lawyer noncompliance claim that the additional opportunities attorneys have to initiate reform lawfully make their civil disobedience unjustified. ${ }^{162}$ Actions that might be defensible if taken by a nonlawyer are inappropriate for lawyers, who have far greater legal options at their disposal. ${ }^{163}$ Other commentators argue that the power attorneys have within the

${ }^{158}$ Freedman, supra note 2, at 1138; cf. THOREAU, supra note 18, at 243 (arguing that even a just government authorized by "the sanction and consent of the governed" had "no pure right over [his] person").

${ }^{159}$ Wilkins, supra note 100 , at 514.

${ }^{160}$ See id. (arguing that lawyers must have the "right to reject the formal requirements of rules and roles in situations when following the official path would produce substantively bad results").

${ }^{161}$ See supra notes 2, 27 and accompanying text (supporting the proposition that civil disobedience is an accepted form of protest).

${ }^{162}$ See Cowen, supra note 2, at 597 (arguing that attorney civil disobedience is rarely justified since lawyers have "a greater opportunity than does the layman to rectify allegedly unjust or immoral laws within the existing legal structure”).

${ }^{163}$ This argument presupposes that the validity of civil disobedience depends, in part, on the unavailability of other forms of protest. Others contend that such an assumption is unnecessarily restrictive on civil disobedience. See, e.g., Luban, supra note 22, at 801 (stating that one's duty to obey the law turns solely on whether the laws are worthy of respect). 
legal system comes with the legitimate expectation that attorneys will exercise it. ${ }^{164}$ Attorneys alone may pull the levers of legal reform, established as a form of democratic protection of citizens. ${ }^{165}$ Thus, when lawyers choose to break the law in protest instead of utilizing the legal options available, they betray their role in our democracy. ${ }^{166}$

There are two responses to this objection. First, a lawyer's power comes hand-in-hand with insight into the legal system that other citizens lack. In addition to giving attorneys a privileged position, a lawyer's professional role provides her with unique opportunities to see the law operate wrongly or unfairly. Attorneys have a better sense of which laws create the greatest injustices and which may actually be improved through noncompliance. Moreover, an attorney's role differs from that of nonlawyers in that they are charged as guardians of the administration of justice. ${ }^{167}$ These differences between members of the legal profession and other citizens may actually make "a lawyer ... particularly well equipped to break or disregard the law as an act of civil disobedience."

In addition, it is possible to exaggerate the power attorneys have within the legal system. We have already seen the ways in which this power is limited. ${ }^{169}$ Even for attorneys, lawful reform of unjust laws

${ }^{164}$ See Wilkins, supra note 86, at 274 ("Lawyers are more than ordinary citizens; they have been given a monopoly by the state to occupy a position of trust both with respect to the interests of their clients and the public purposes of the legal framework.").

${ }^{165}$ See id. (describing the role of lawyers as monopolistic and noting that this role is tied to the social good).

${ }^{166}$ Not everyone agrees that lawyers should be regarded as playing a unique role within our society. See Charles Fried, The Lawyer as Friend: The Moral Foundations of the Lawyer-Client Relation, 85 YALE L.J. 1060, 1080 (1976) ("Some of the more ecstatic critics have put forward the lawyer as some kind of anointed priest of justice ... But this is wrong. In a democratic society, ... . [e]very citizen has the same duty to work for ... the establishment of just institutions, and the lawyer has no special moral responsibilities in that regard." (footnote omitted)).

${ }^{167}$ See supra notes 47-49 and accompanying text (noting the duty imposed on lawyers to improve the law).

${ }^{168}$ Carrie Menkel-Meadow, Private Lives and Professional Responsibilities? The Relationship of Personal Morality to Lawyering and Professional Ethics, 21 PACE L. REV. 365, 388 (2001); see also Luban, supra note 28, at 259 (“[B] ecause lawyers are often better positioned than nonlawyers to realize the unfairness or unreasonableness of a law, lawyers often should be among the first to violate or nullify it, or to counsel others that it is acceptable to violate or nullify it.").

${ }_{169}$ See text accompanying notes 55-58 (describing the limits on lawful reform by lawyers). 
may be either impossible or strictly limited. ${ }^{170}$ A lawyer may be the only individual who can protest the law, and civil disobedience may be the only way to lodge such protests. Thus, the power of attorneys alone should not prevent us from explicitly tolerating their civil disobedience.

\section{Proposals for Official Treatment of ATTORNEY CIVIL DISOBEDIENCE}

The current rules of legal ethics overdeter attorney civil disobedience due to the simple fact that they do not address it directly. Attorneys are left with little guidance from the organized bar about which principles, if any, constitute a moral justification for violating the law. Moreover, the ethics rules are of little help in determining the professional consequences of disobedience. ${ }^{171}$ With so much uncertainty about civil disobedience in the law governing lawyers, committing it remains a high stakes gamble. As demonstrated in Part III, the justifications for excluding a more forthright discussion of conscientious noncompliance in the Model Code and Model Rules are weak. Recognizing the option of attorney civil disobedience will not threaten the public's respect for the law, the legal system, or the legal profession.

Even the critics of attorney civil disobedience agree that there are some instances in which it is unreasonable to impose on lawyers a categorical duty to obey the law. The case of Nazi Germany presents a moral baseline at which these commentators concur that noncompliance is justified. ${ }^{172}$ The more complicated issue is how to define a lawyer's duty to obey the law in legal regimes, such as ours, that are "generally just." In this section, I will propose amendments to the Model Rules to better identify and accommodate instances of justified civil disobedience in the context of the American legal system.

${ }^{170}$ See Minow, supra note 37, at 727-39 (describing the limits on lawful reform, the potential negative consequences in pursuing it, and the advantages that civil disobedience offers in certain situations).

${ }^{171}$ See supra Part II (discussing the uncertain treatment in the legal ethics rules and case law of attorney civil disobedience).

${ }^{172}$ See Terrell, supra note 28, at 833-34 (acknowledging that lawyers in a thoroughly unjust system may justifiably disobey the law); Wilkins, supra note 86 , at 285 ("[N]ot even the most ardent defenders of the Dominant View of legal ethics, or of Positivism more generally, believe that either lawyers or citizens are under an absolute moral obligation to obey the law no matter how evil or corrupt.").

${ }^{173}$ See Wilkins, supra note 86, at 285 (noting that the important question is how to define the bar's prima facie obligation to obey the law). 


\section{A. Defining Civil Disobedience}

Civil disobedience should be incorporated into the Model Rules as a defense to mitigate the effects of the charge that an attorney has violated her legal duties. ${ }^{174}$ To recognize such a defense in the codes, we must define what constitutes civil disobedience. This task

${ }^{174}$ The difficulty of identifying attorney civil disobedience in some cases is illustrated by the recent development of multidisciplinary practices (MDPs). The most prominent types of MDPs are those which offer business consulting, financial planning, and legal services to their clients all at once by "partnering . . lawyers and nonlawyers in multi-task service firms." Jeffrey M. Jones, Comment, Bend, but Don't Break: MDP Proposal Bends in the Right Direction, but-Crack!!-Goes Too Far, 54 SMU L. REV. 395, 395 (2001). While they provide the advantages of "one-stop shopping" to clients, lawyers working in MDPs routinely breach ethics rules about fee sharing, conflicts of interest, and client confidentiality. See id. ("But despite the business efficiencies of MDPs, such a combination of services is wrought with ethical difficulty."); see also Linda Galler, Problems in Defining and Controlling the Unauthorized Practice of Law, 44 ARIZ. L. REV. 773, 774 (2002) (citing an ABA resolution that rejected MDPs by spelling out the core values that MDPs would ostensibly violate).

Some observers have argued that MDPs are "blatantly violating" the rules of legal ethics and that their lawyers are engaged in massive civil disobedience, essentially daring bar disciplinary boards to try to stop them. See Lawrence J. Fox, Accountants, the Hawks of the Professional World: They Foul Our Nest and Theirs Too, Plus Other Ruminations on the Issue of MDPs, 84 MINN. L. REV. 1097, 1097, 1105 (2000) [hereinafter Accountants Are Hawks] (describing the hiring of thousands of lawyers by the Big 5 accounting firms as civil disobedience); Lawrence J. Fox, Those Who Worry About the Ethics of Negotiation Should Never Be Viewed as Just Another Set of Service Providers, 52 Mercer L. Rev. 977, 988 (2001) (arguing that accountants have tried to justify "the civil disobedience of the thousands of lawyers they have hired"); see also Galler, supra, at 774 (proposing solutions to address the civil disobedience of the accounting firm MDPs and their lawyers).

Other observers believe that, whatever the transgressions of MDPs, characterizing their growth as civil disobedience goes well overboard. See, e.g., Erica Blaschke Zolner, Comment, Jack of All Trades: Integrated Multidisciplinary Practice, or Formal Referral System? Emerging Global Trends in the Legal and Accounting Professions and the Need for Accommodation of the MDP, 22 NW. J. INT'L L. \& BUS. 235, 252-53 (2001) (criticizing the claim that lawyers at MDPs are engaging in civil disobedience as a "doomsday prediction" that inaccurately depicts a crisis in the legal profession). The MDPs themselves, as they interpret the rules of ethics, argue that they have not violated them, conscientiously or otherwise. See Fox, Accountants Are Hawks, supra, at 1100 (reciting the MDP argument that their lawyers are not subject to the rules of professional ethics because they are not practicing law).

No one-especially not the bar-seems to know quite how to handle the MDPs. Their practices represent a significant and intentional departure from current professional norms, but enforcement of the ethics provisions supposedly violated by MDPs has remained lax, and MDPs vigorously fought the few enforcement proceedings brought against them. See Jones, supra, at 425-26 (remarking that there is "very little in the way of enforcement [of the disciplinary rules] to show" for all the concern about MDPs, and reporting that an enforcement action against an MDP failed because the MDP "simply overwhelmed the bar with a phalanx of defense lawyers" (quoting Krysten Crawford, The Enemy Has Landed, and They Count Beans, AM. LAW., Dec. 1998, at 16)). 
is more difficult than it would first seem. There is a wide range of attorney behavior that falls within the "gray areas" of positive law, with the result being that there are times when it may be difficult to pin down which actions constitute actual noncompliance. This is especially true when the alleged wrongdoer refuses to acknowledge her offense.

A definition of civil disobedience in the ethics rules should include four elements. First, the act constituting civil disobedience must be public. An attorney's actions should only fall within the definition if she acknowledges that she has broken the law and offers civil disobedience as a defense. Though there may be instances in which nonpublic lawbreaking is more effective for ensuring a just result, such behavior does not demonstrate the respect for the law that redeems an attorney's defiance and gives the system an opportunity to respond. ${ }^{175}$ Moreover, if a nonpublic violation were to become public, it would undermine trust in the legal profession much more than if it had been public from the beginning. ${ }^{17}$

Second, the disobedience must be nonviolent. A civil disobedience defense cannot be a safe harbor for violence. Noncompliance with unjust laws loses its legitimacy when it is violent. ${ }^{177}$

Third, the attorney must offer an explanation of her defiance based on moral or religious conviction. ${ }^{178}$ David Luban has persuasively argued that the obligation to obey the law can be understood, in part, as an obligation to our fellow citizens. ${ }^{179}$ When attorneys (and other citizens) seek to convince the legal system that violating this obligation was justified, they owe their fellow citizens an explanation of why they believed the law was "wrong, stupid, or unfair." 180 Though identifying when an attorney's moral or religious beliefs actually compel her to violate the law is a delicate matter, the jurisprudence regarding conscientious objectors to military service provides a helpful comparison. Citizens have been relieved from their military duty on grounds of ethical standards that had a "functional role in

${ }^{175}$ See Zacharias, supra note 124, at 214-16 (discussing the problems caused by secret conscientious objection by attorneys).

${ }^{176}$ See id. at 215-16 (" $[\mathrm{S}]$ ecret conscientious objection may contribute to the public's general image of ineffective or disloyal lawyering . . . .").

${ }^{177}$ Cf. King, supra note 10 (describing the legitimacy of nonviolent direct action).

178 See Griffin, supra note 50, at 1259-61 (arguing that the civil disobedience model is appropriate for lawyers who break the law for religious reasons).

${ }^{179}$ See LubAN, supra note 37, at 35-43 (explaining the proposition that respect for the law is "respect for our fellows").

${ }^{180}$ Id. at 47. 
guiding the objector's behavior throughout his everyday activities," when these beliefs were held extremely deeply, and when the objector demonstrated his strength of convictions by accepting punishment. ${ }^{181}$ These standards provide the bar with a touchstone by which to judge whether an attorney's asserted moral commitments are genuine.

Finally, civil disobedience should exclude activities motivated primarily by material self-interest. ${ }^{182}$ An attorney who cannot establish this element is unlikely to succeed in establishing the previous one either. Explicitly stating this requirement, however, emphasizes-to the legal profession and to the public - the features of self-sacrifice and concern for the public interest that are central to civil disobedience.

\section{B. Limiting Disciplinary Discretion}

Commentators disagree on how much discretion should be afforded to disciplinary bodies in punishing attorneys who engage in civil disobedience. Generally, those scholars who wish to restrict discretion in punishing defiant attorneys are those who are also skeptical of the propriety of attorney civil disobedience. ${ }^{183}$ I believe, however, that a call for constrained discretion in the bar's disciplinary system is an important element of making the legal profession more tolerant of lawyer noncompliance.

There are two ways in which disciplinary discretion should be limited. First, I propose to limit the range of professional consequences that attorneys currently face for civil disobedience. The ethics rules currently provide no hint of the consequences of conscientious noncompliance. Rather, attorneys are left to gamble on the response of the bar's disciplinary authorities, with little help in determining whether their disobedience will be ignored, result in a slap on the wrist, or cost them their licenses. ${ }^{184}$ Without a clear picture of the risk to their careers, attorneys cannot make an informed evaluation of whether they should conscientiously violate a law. Establishing a more

${ }^{181}$ See Zacharias, supra note 124, at 202-05 (discussing legal standards for granting conscientious objector status)

${ }^{182}$ Cf. Luban, supra note 28, at 259 n.34 (suggesting that civil disobedience should exclude actions taken by a lawyer for "intended pecuniary gain").

${ }^{183}$ See, e.g., Terrell, supra note 28, at 831-34 (opposing increased discretion in interpreting the rules and criticizing attorney civil disobedience in a "generally just" legal system).

${ }^{184}$ See supra text accompanying note 77 (describing the uncertainty about the bar's response to civil disobedience). 
limited range of punishment within the ethics rules for disciplining civil disobedience will allow lawyers to consider noncompliance more thoughtfully. Because of a lawyer's heightened duty to obey the law, some professional disciplinary consequences are appropriate for attorneys who commit civil disobedience. ${ }^{185}$ But at the same time, the professional penalty to attorneys cannot be so great that their very ability to practice law may be at stake, as it currently is. ${ }^{186}$ Attorneys should be subject, at the very worst, to no more than a temporary suspension of their ability to practice.

I also propose to limit the ability of disciplinary counsel to turn a blind eye to attorney civil disobedience. ${ }^{187}$ As Professor Bruce Green has observed, the attitude of disciplinary counsel towards conscientious lawbreaking is often that lawyers should go ahead and do it, but "[j] ust don't tell us about it." undermines the justifications for and effectiveness of attorney civil disobedience in several ways. First, the exercise of such discretion strips civil disobedience of its value as a tool for improving the law. By giving a defiant attorney a pass, the bar minimizes the law-morality conflict that the lawyer's disobedience highlights. This robs both the bar and the legal system of an opportunity to publicly evaluate the attorney's criticism and to adequately consider the most appropriate response. Second, attorneys who have committed civil disobedience show their respect for the law by accepting punishment. If lawyers face no disciplinary proceedings for their violations, this element of respect is not displayed to the public. This potentially undermines the public's respect for the law and for the legal profession. ${ }^{189}$ Finally, prosecutorial discretion detracts from the generality of the ethics rules and weakens their moral authority. ${ }^{190}$ This is contrary to the purpose of civil disobedience, which is to strengthen legal authority, not to undermine it.

${ }^{185}$ See supra notes 148-49 and accompanying text (discussing a lawyer's increased responsibility to obey the law).

${ }^{186}$ See Terrell, supra note 28, at 835-36 (noting that disbarment is a potential consequence of civil disobedience).

${ }^{187}$ Compare id. at 840 (arguing against increasing discretion within legal ethics to accommodate civil disobedience), with Strassberg, supra note 23, at 951-52 (supporting increased prosecutorial discretion for justified noncompliance).

${ }^{188}$ Green, supra note 77, at 1308 (quoting an unidentified disciplinary counsel).

189 See supra Part III.A-B (discussing how attorneys show respect for the law by accepting punishment willingly).

${ }^{190}$ See supra note 107 and accompanying text (noting that the fairness and generality of the law is the feature that earns it our respect). 


\section{CONCLUSION}

Though lawyers must often resolve conflicts between their legal duties and their moral obligations, the Model Rules and Model Code provide little guidance to attorneys for resolving these struggles. The ethics rules are unhelpful in determining if or when moral principles outweigh a lawyer's obligation to obey the law, leaving attorneys who wish to engage in civil disobedience to gamble their careers on the discretion of the bar's disciplinary authorities. Moreover, the arguments offered for continuing to ignore conscientious noncompliance in the codes of ethics are unpersuasive.

The legal profession should directly address the issue of civil disobedience in its rules of ethics. The bar will be strengthened by the explicit acknowledgement that moral considerations can supercede even an attorney's legal duties. Our society expects lawyers, who remain its most important custodians of the law's fairness and justice, to exercise moral judgment for the good of our legal system. As Gandhi's example teaches us, an attorney need not sacrifice her respect for the law or undermine her role in the legal system by committing civil disobedience. It is past time for the bar to recognize the possibility that an attorney may best fulfill her duties to the law and to our society through conscientious noncompliance. 